\title{
Designation of a new family group name, Tonzidae fam. nov., for the genus Tonza (Lepidoptera, Yponomeutoidea), based on immature stages of Tonza citrorrhoa
}

\author{
Shigeki KOBAYASHI ${ }^{1,}$, Haruka MATSUOKA ${ }^{2}$, Masaaki KIMURA ${ }^{3}$, Jae-Cheon $\mathrm{SOHN}^{4}$, \\ Yutaka YOSHIYASU ${ }^{5} \&$ David C. LEES ${ }^{6}$ \\ ${ }^{1,2,5}$ Entomological Laboratory, Graduate School of Life \& Environmental Sciences, \\ Osaka Prefecture University, Sakai, Osaka, 599-8531 Japan. \\ ${ }^{3}$ Ga-show Ltd., Tomari, Naha, Okinawa, 900-0012 Japan. \\ ${ }^{4}$ Institute of Littoral Environment, Mokpo National University, Yeongsanro 1666, \\ Cheonggye, Muan, Jeonnam 58554, South Korea. \\ ${ }^{6}$ The Natural History Museum, Cromwell Road, London SW7 5BD, United Kingdom. \\ "Corresponding author: crossroad1994@hotmail.co.jp \\ ${ }^{2}$ Email: catfish_redtailcat@yahoo.co.jp \\ ${ }^{3}$ Email: ga-show.kimura@nifty.ne.jp \\ ${ }^{4}$ Email: jay.c.sohn@gmail.com \\ ${ }^{5}$ Email: yosiyasu@kpu.ac.jp \\ ${ }^{6}$ Email: davil@nhm.ac.uk

\footnotetext{
${ }^{1}$ urn:lsid:zoobank.org:author:5A3A485F-95E4-4CA0-9693-E996C9B2A9D2

${ }^{2}$ urn:lsid:zoobank.org:author:56AE5FE9-77C9-4FA4-9F4A-31A9450A9F3F

${ }^{3}$ urn:lsid:zoobank.org:author:F6265053-D7FD-4497-910E-AA9B0F2AB568

${ }^{4}$ urn:1sid:zoobank.org:author:84687C58-E0A2-4706-9A17-20B589243993

${ }^{5}$ urn:lsid:zoobank.org:author:50B2933B-ABF8-4C6A-B8F8-A68FE823998F

${ }^{6}$ urn:1sid:zoobank.org:author:ADC0E307-B009-4BE5-A3BD-EEFBF43A132D
}

\begin{abstract}
The systematic position of Tonza Walker, 1864 is re-evaluated, based on the characteristics of immature stages and DNA barcodes. Larvae and pupae of Tonza citrorrhoa Meyrick, 1905 are described and illustrated for the first time. Larvae of this species form a loose web among the leaves and branches of the host plant, Putranjiva matsumurae Koidz. (Putranjivaceae Endl.). The immature stages of Tonza exhibit four unique apomorphies including: in the larva, the prolegs on A5 and A6 absent, and the seta L2 on the A1-A8 very small; in the pupa, four minute knobs are positioned in the middle portion on abdominal segments V and VI; while its caudal processes possess a $\mathrm{W}$-shaped spine with numerous minute spines. These characteristics clearly distinguish Tonza from other yponomeutoid families and hence, we propose a new family group name, Tonzidae Kobayashi \& Sohn fam. nov., for the genus Tonza. Existing DNA barcode data suggest a relationship with Glyphipterigidae Stainton, 1854. The family level status of Tonzidae fam. nov. provides a hypothesis that needs to be tested with larger molecular data.
\end{abstract}

Keywords. Adenosma, Bedelliidae, DNA barcoding, Putranjiva matsumurae, leaf webber. 
Kobayashi S., Matsuoka H., Kimura M., Sohn J.C., Yoshiyasu Y. \& Lees D.C. 2018. Designation of a new family group name, Tonzidae fam. nov., for the genus Tonza (Lepidoptera, Yponomeutoidea), based on immature stages of Tonza citrorrhoa. European Journal of Taxonomy 443: 1-32. https://doi.org/10.5852/ejt.2018.443

\section{Introduction}

Tonza Walker, 1864 is a small genus of moths from Australia and Asia (Sri Lanka, Taiwan, Japan, and Solomon Is.). This genus was originally assigned to Plutellidae Guenée, 1845 (Walker 1864). Since then, the majority of authors (e.g., Common 1990; Heppner 1992) has followed the original assignment. However, no previous publications provided convincing evidence supporting the plutellid association of Tonza.

Recently, Kobayashi et al. (2015) recorded T. citrorrhoa Meyrick, 1905 from Japan and described the wing venation and genital structures of Tonza for the first time. Furthermore, they reevaluated the previously suggested association of Tonza with Plutellidae. The diagnostic characters of Tonza include: antenna almost the same length as forewing; forewing with only three radial plus radial sector veins; in the male genitalia, both uncal processes and the socii present; in the female genitalia, lamella antevaginalis strongly sclerotized. These morphological features of Tonza along with absence of ocelli clearly disputed its plutellid association and seemed to associate Tonza with the yponomeutoid family Attevidae Bruand, 1850 (Kobayashi et al. 2015). However, a formal family transfer was pending until the immature stages of Tonza became known.

In this paper, the immature stages of Tonza are described for the first time for T. citrorrhoa from Japan with photographs and drawings: the later instar larvae, pupae and life history. We propose a new family group name, Tonzidae Kobayashi \& Sohn fam. nov., for the genus Tonza and discuss its relationships with other yponomeutoid families, based on larval and pupal morphology.

\section{Material and methods}

Larvae were collected from spinnings among the leaves and branches of Putranjiva matsumurae Koidz. by the third author (M. Kimura) in April, 2016 on Yonaguni Is., Okinawa Prefecture. Those were taken to the lab and reared in plastic cups (420 $\mathrm{ml}: 129 \mathrm{~mm}$ in top diameter and $60 \mathrm{~mm}$ in depth) containing wet cotton on the bottom. The cups were maintained in the laboratory at $20 \pm 5^{\circ} \mathrm{C}$ and at $13-16 \mathrm{~L}: 8-12 \mathrm{D}$ photoperiodic conditions. Some samples were preserved in $99 \%$ ethanol for DNA sequencing. Emerged adult specimens were preserved in the Osaka Prefecture University (OPU). Some samples of the larvae, the pupae and the adults were dried and sputter-coated with a 60:40 mixture of gold-palladium for scanning electron microscope (SEM). SEM photographs were taken using a Hitachi SU1510 (Hitachi Ltd., Tokyo, Japan) with a lanthanum hexaboride (LaB6) cathode source at an accelerating voltage of 15 $\mathrm{kV}$. For genital dissections, the whole abdomen was removed, macerated for 3-4 min in 10\% aqueous $\mathrm{KOH}$, and brushed in $70 \%$ ethanol to remove residual scales and soft parts. Genitalia were then stained in acetocarmine for 1-2 h, dehydrated in a series of 70-100\% ethanol and mounted in Canada balsam on a glass slide. For the observations of larval structure, the alcohol-fixed larvae were macerated for 5-6 min in 10\% aqueous $\mathrm{KOH}$ and the right lateral side of the body was opened up, followed by removal of residual inner soft parts in $70 \%$ ethanol. The larval surface skin was then stained and mounted using the same methods as the genitalia. Larvae of Atteva aurea Fitch, 1856 were collected by the fourth author (JCS) and Scythropia crataegella Linnaeus, 1767 was obtained from Dr. Ian Sims (UK). Nomenclature for genitalia follows Sohn \& Nishida (2011). Nomenclature for larval characters follows Stehr (1987). Scientific names of plants follow the Plant List (www.theplantlist.org). 
KOBAYASHI S. et al., Designation of a new family group name, Tonzidae fam. nov.

Table 1. Sampling information and GenBank accession numbers.

\begin{tabular}{|c|c|c|c|c|}
\hline Species name & Family name & $\begin{array}{l}\text { Collection } \\
\text { country }\end{array}$ & $\begin{array}{c}\text { GenBank } \\
\text { accession no. COI }\end{array}$ & $\begin{array}{l}\text { Sequence } \\
\text { length (bp) }\end{array}$ \\
\hline Tonza citrorrhoa Meyrick, 1905 & Tonzidae fam. nov. & Japan & LC310893 & 686 \\
\hline Ortenches epiphricta Meyrick, 1907 & Plutellidae & Australia & HQ922367 & 658 \\
\hline Plutella xylostella Linnaeus, 1758 & Plutellidae & Korea & DQ076411 & 681 \\
\hline Saridoscelis kodamai Moriuti, 1961 & Yponomeutidae & Japan & KF492103 & 657 \\
\hline Swammerdamia pyrella Villers, 1789 & Yponomeutidae & Finland & KT782599 & 658 \\
\hline Yponomeuta cagnagellus Hubner, 1813 & Yponomeutidae & Finland & KT782553 & 658 \\
\hline Zelleria haimbachi Busck, 1915 & Yponomeutidae & Canada & KT148240 & 658 \\
\hline Ypsolopha parallela Caradja, 1939 & Ypsolophidae & Korea & KF523860 & 658 \\
\hline Glyphipterix equitella Scopoli, 1763 & Glyphipterigidae & Denmark & KT782432 & 658 \\
\hline Orthotelia sparganella Thunberg, 1788 & Glyphipterigidae & Norway & KX048240 & 657 \\
\hline Atteva albiguttata Zeller, 1873 & Attevidae & Australia & HQ922342 & 658 \\
\hline Atteva aurea Fitch, 1856 & Attevidae & Canada & GU013569 & 665 \\
\hline Atteva hysginiella Wallengren, 1861 & Attevidae & $\begin{array}{l}\text { Ecuador: } \\
\text { Galapagos Is. }\end{array}$ & HM034104 & 658 \\
\hline Atteva zebra Duckworth, 1967 & Attevidae & Costa Rica & GU692470 & 658 \\
\hline Prays autocasis Meyrick, 1907 & Praydidae & Australia & JF840378 & 658 \\
\hline Prays fraxinella Bjerkander, 1784 & Praydidae & Germany & KX044853 & 658 \\
\hline Prays ruficeps Heinemann, 1854 & Praydidae & Germany & KX044999 & 658 \\
\hline Heliodines tripunctella Walsingham, 1892 & Heliodinidae & USA & KF492395 & 658 \\
\hline Bedellia somulentella Zeller, 1847 & Bedelliidae & Canada & KT139550 & 658 \\
\hline Scythropia crataegella Linnaeus, 1767 & Scythroplidae & Germany & KX046825 & 658 \\
\hline Caloptilia belfrageella Chambers, 1875 & Gracillariidae & Canada & KJ165583 & 658 \\
\hline Phyllocnistis citrella Stainton, 1856 & Gracillariidae & USA & KF919121 & 658 \\
\hline Roeslerstammia erxlebella Fabricius, 1787 & Roeslerstammiidae & Italy & JN307285 & 658 \\
\hline
\end{tabular}

\section{Molecular analysis}

The DNA barcode region ( $658 \mathrm{bp}$ ), a part of the mitochondrial cytochrome c oxidase subunit I(COI) gene, was chosen for sequencing. This marker has been popularly used for inferring the relationships among closely related moth species and populations (Brown et al. 1994) One emerged adult of T. citrorrhoa was preserved in $99 \%$ ethanol for DNA sequencing (voucher no. SK-097). Total genomic DNA was extracted from the mid- and hind legs. Polymerase chain reaction (PCR) was carried out to obtain the DNA barcode region, using the primer LCO1490 (fwd) (5'-ggt caa caa atc ata aag ata ttg g-3') and HCO2198 (rev) (5'taa act tca ggg tga cca aaa aat ca-3') (Folmer et al. 1994) in a thermal cycler C1000 (Bio-Rad, Hercules City, CA, USA) under the following conditions: initial $120 \mathrm{~s}$ denaturation at $94^{\circ} \mathrm{C}$, and 39 alternating cycles of $15 \mathrm{~s}$ at $94^{\circ} \mathrm{C}$ for denaturation, $30 \mathrm{~s}$ at $52^{\circ} \mathrm{C}$ for annealing, and $60 \mathrm{~s}$ at $72^{\circ} \mathrm{C}$ for extension. PCR products were purified, after that they were sequenced using an automated DNA sequencer (ABI Prism 3100; Applied Biosystems, Foster City, CA, USA). The sequences were aligned using MEGA6 (Tamura et al. 2013) and Geneious v. 10.1.3 (Kearse et al. 2012). The aligned data were analyzed using RAxML installed in the CIPRES portal (https://www.phylo.org/). The outgroup sequences were obtained from GenBank (https://www.ncbi.nlm.nih.gov/genbank/) and accession numbers are shown in Table 1. A new sequence is deposited in DNA Data Bank of Japan (DDBJ) (accession no. LC310893).

\section{Abbreviations}

NHMUK $=$ Natural History Museum, Department of Zoology (Formerly the British Museum [Natural History] or BMNH), London, United Kingdom.

USNM = National Museum of Natural History, Smithsonian Institution, Washington DC, USA. 


\title{
Results
}

\author{
Class Hexapoda Blainville, 1816 \\ Order Lepidoptera Linnaeus, 1758 \\ Superfamily Yponomeutoidea Stephens, 1829 \\ Family Tonzidae Kobayashi \& Sohn fam. nov. \\ urn:1sid:zoobank.org:act:3E5EB9E2-2A60-4D77-94C5-6F02A7A92F44
}

Figs 1-13

\section{Type genus}

Tonza Walker, 1864.

\section{Diagnosis}

ADULT. Maxillary palpi three-segmented; ocelli and chaetosema absent (Fig. 8C-D); antennae slightly longer than or same length as forewing (Fig. 1); forewings with slightly protruding apex and tornus; forewing termen oblique or concave; only two radial sector veins present, RS1 on apex and RS2 on termen (Kobayashi et al. 2015; Fig. 1F); in the male genitalia (Kobayashi et al. 2015; Fig. 2A-D), uncus small with a pair of long processes; socii with long terminal setae; valva elongate with several small spines and plate arising from middle to base of valva; in the female genitalia (Kobayashi et al. 2015; Fig. 2E), lamella antevaginalis sclerotized, covering sternite VIII; antrum slender; inception of ductus seminalis at the middle of corpus bursae (after Kobayashi et al. 2015).

Mature LaRva (baSed on T. citrorrhoa). Seta L2 on A1-A8 very small (Fig. 6C-D); Seta D1 of A9 segment markedly more slender than D2 (Fig. 6E); A3, A4 and A10 with the ventral prolegs absent for A5 and A6 (Fig. 4A, G).

PuPA. Vertex with triangular frontal process (Fig. 10A-D); dorsum of A2-A9 without spines (Fig. 7BC); four minute knobs postioned in the middle portion on A5 and A6 (Fig. 10C-F); lateral side of abdomen with protuberances at spiracles (Fig. 7B); A10 furcate with Y-shaped caudal processes, slightly
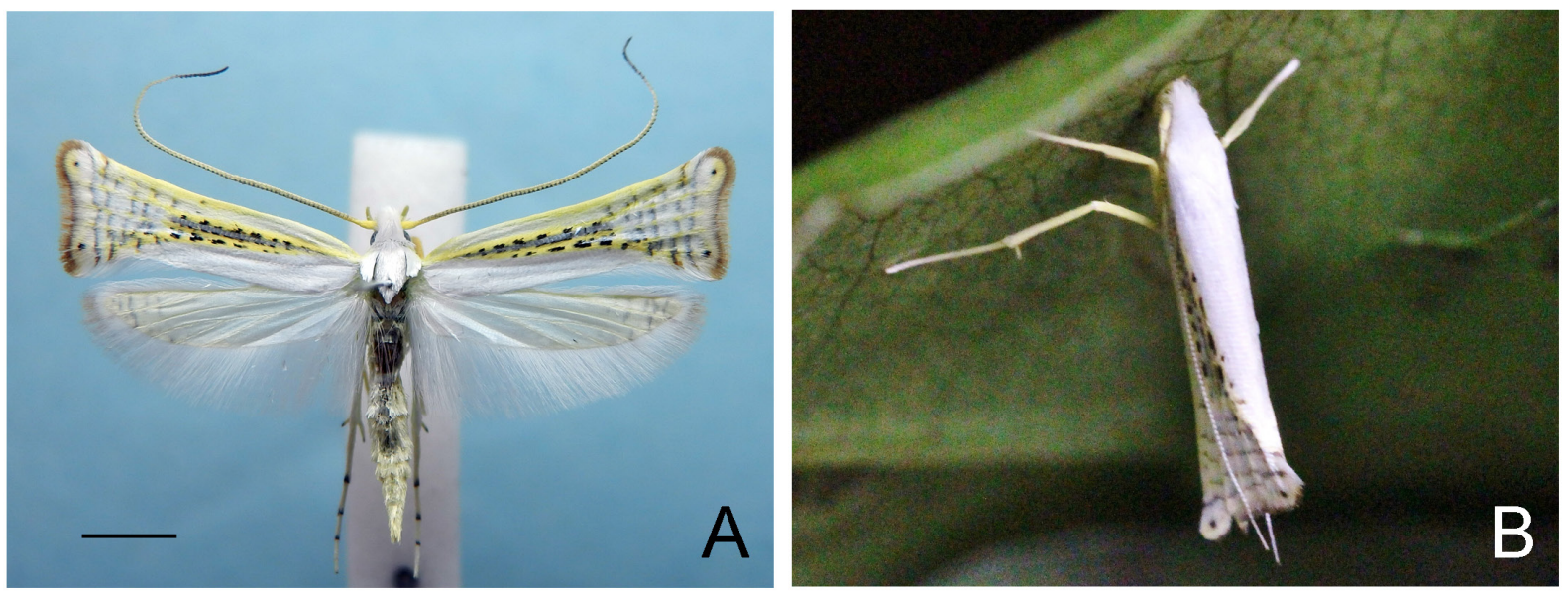

Fig. 1. Female adult of Tonza citrorrhoa Meyrick, 1905 (OPU-IN-LE 2018IV0005), host: Putranjiva matsumurae Koidz., from Yonaguni Is., Okinawa Pref., Japan. A. Adult specimen. B. Resting posture of adult, dorso-lateral view. Scale bar: $2 \mathrm{~mm}$. 


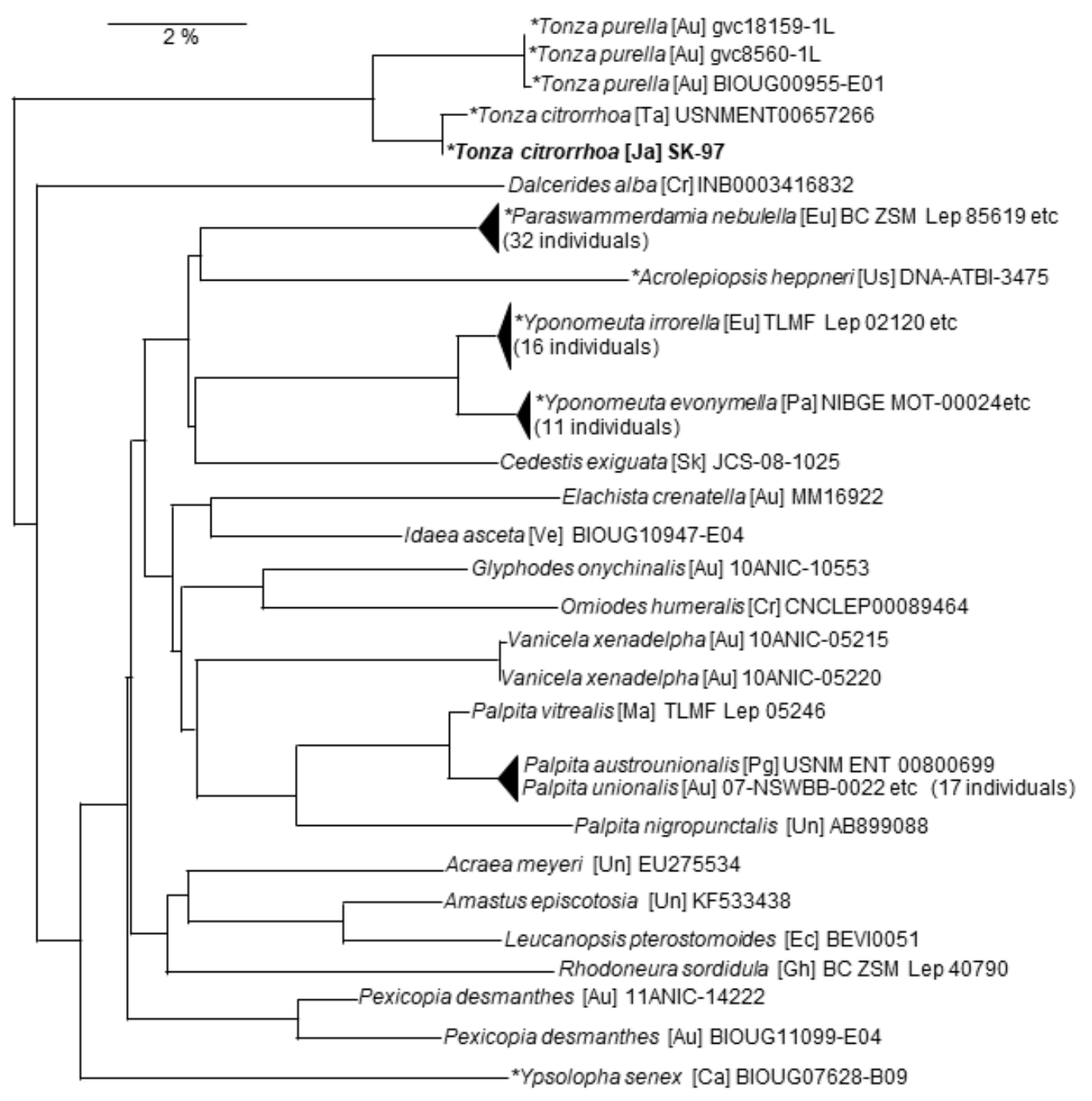

Fig. 2. A tree estimated by neighbor-joining analysis under Kimura's two-parameter distance model using DNA barcode sequence, retrieved from BOLD identification system (IDS). Branch lengths are proportional to distances. Sequence with ID started from "SK-" is obtained from the present study, and the others are from the BOLD database. The letters within square brackets refer to the collection site of specimens as follows: $\mathrm{Au}=$ Australia; $\mathrm{Ca}=\mathrm{Canada} ; \mathrm{Cr}=$ Costa Rica; $\mathrm{Ec}=$ Ecuador; $\mathrm{Eu}=$ Europe; $\mathrm{Gh}=$ Ghana; Ja = Japan; $\mathrm{Ma}=$ Macedonia; $\mathrm{Pa}=$ Pakistan; $\mathrm{Pg}=$ Papua New Guinea; $\mathrm{Sk}=$ South Korea; $\mathrm{Ta}=$ Taiwan; Un = Unknown; Us = United States; Ve = Venezuela. Asterisks show the superfamily Yponomeutoidea. 

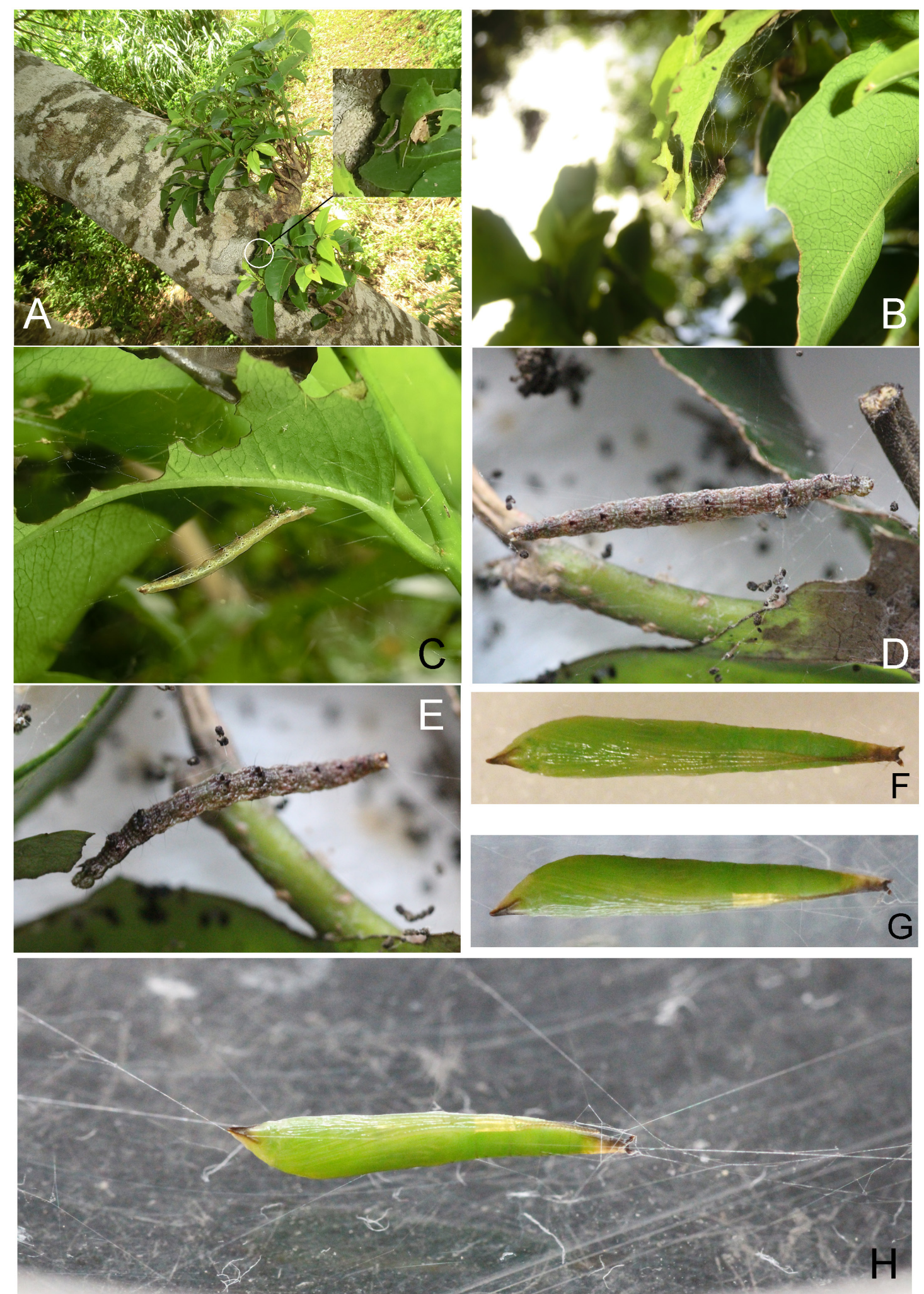

Fig. 3. Larvae and pupae of Tonza citrorrhoa Meyrick, 1905 on Putranjiva matsumurae Koidz. A. Tree of hostplant and larval webs. B. Later larva forming web on young leaves. C. Later larva, lateral view. D. Mature larva, dorsal view. E. Same, ventral view. F. Pupa, ventral view. G. Same, lateral view. H. Pupa at the joint of some cross silken threads, lateral view. 

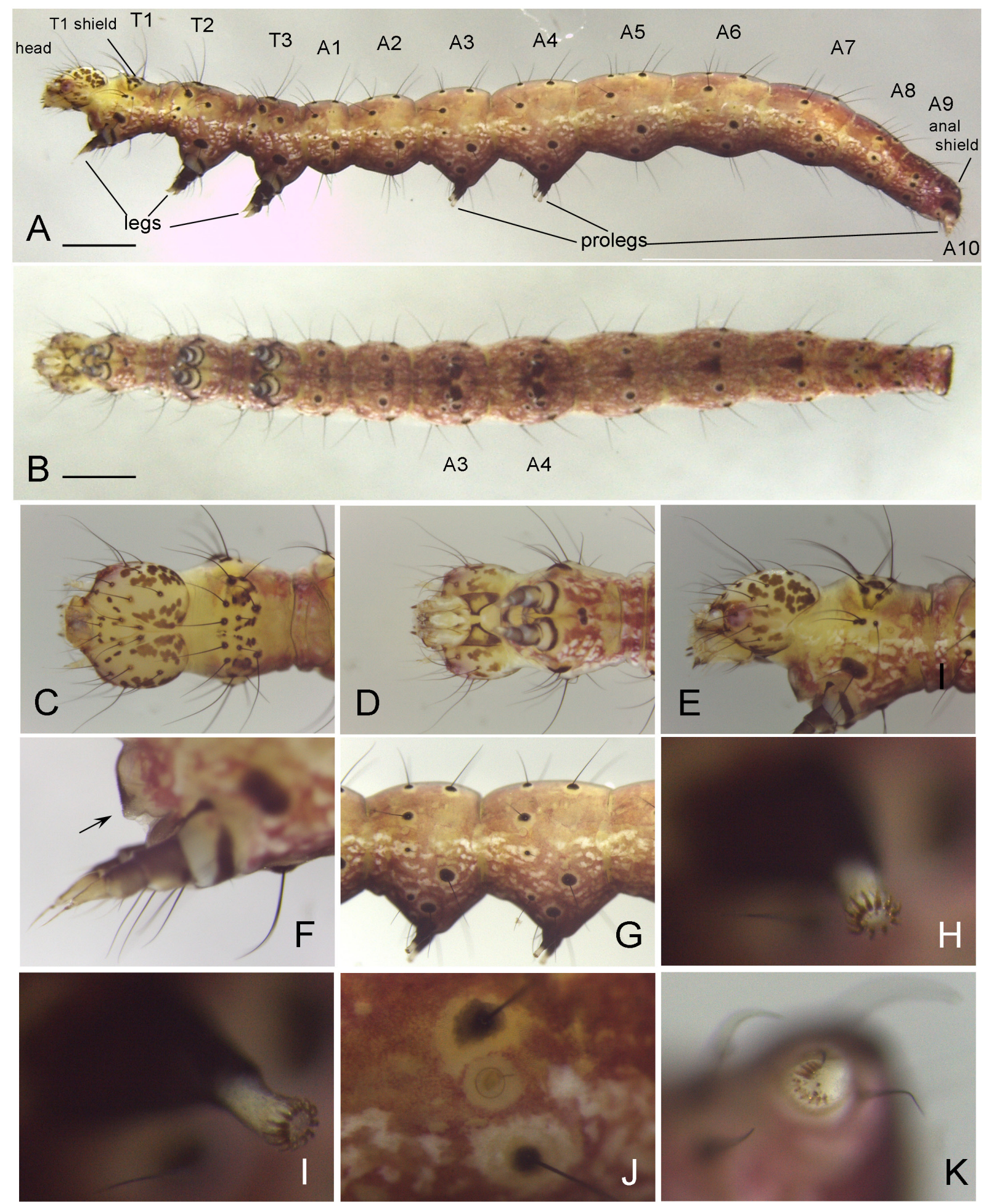

Fig. 4. Mature larva of Tonza citrorrhoa Meyrick, 1905 (OPU-IN-LE2018IV0031|SK600). A. General, lateral view. B. Same, ventral view. C. Head and prothorax, dorsal view. D. Same, ventral view. E. Same, lateral view. F. Jugular glands, lateral view. G. A3, 4. H. Proleg on abdominal segment 3. I. Same, on abdominal segment 4. J. Spiracle on abdominal segment 8. K. Anal proleg, ventral view. Scale bar: $1 \mathrm{~mm}$. 

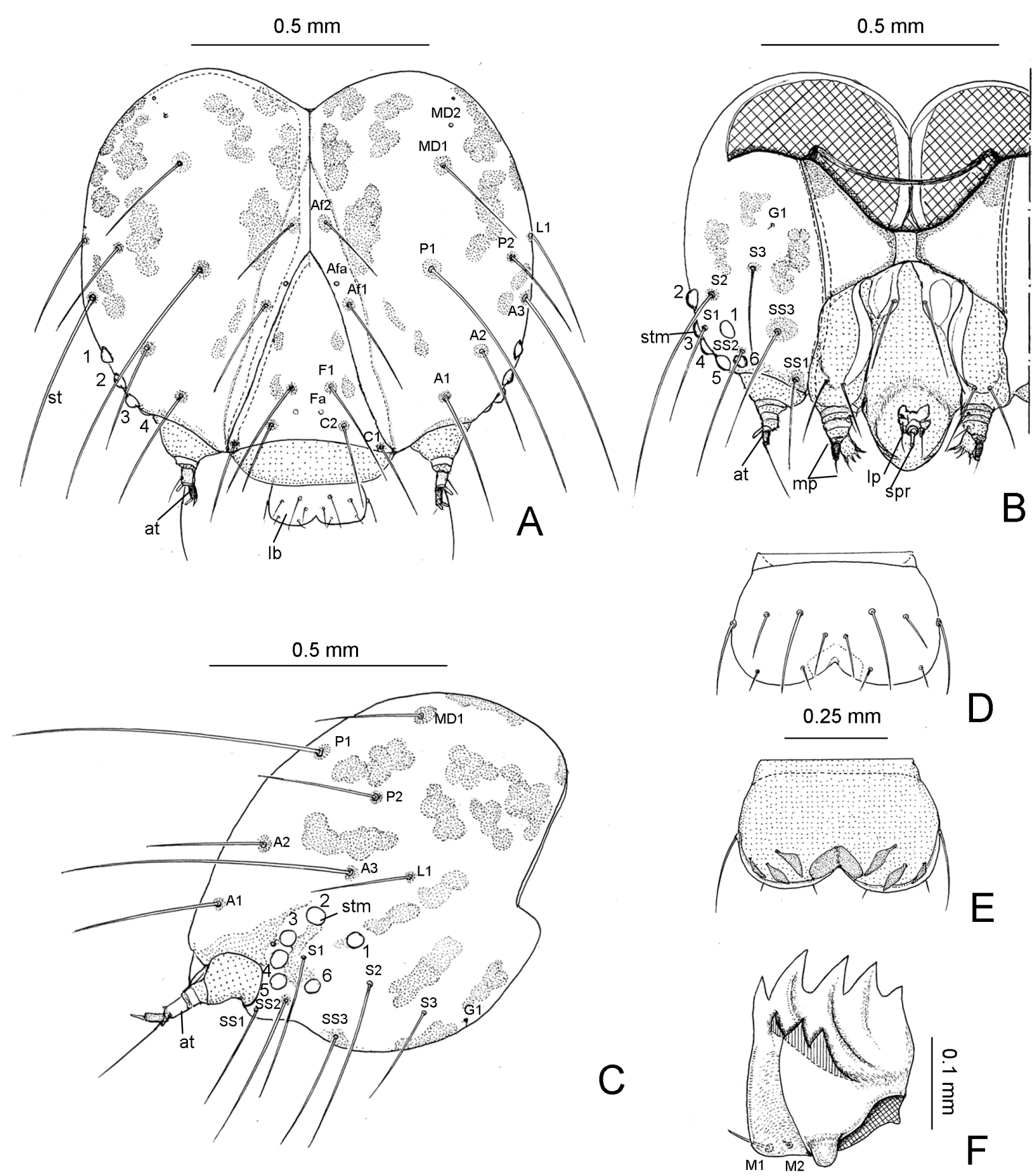

Fig. 5. Mature larval head of Tonza citrorrhoa Meyrick, 1905 (OPU-IN-LE2018IV0031|SK600, 0025|SK603, 0026|SK604). A. Head capsule, frontal view. B. Same, rear view. C. Same, lateral view. D. Labrum, frontal view. E. Same, rear view. F. Mandible, inner view. Abbreviations: A1, A2, A3 = anterior setae; Af1, Af2 = adfrontal setae; Afa = pore between setae Af1 and Af2; at = antenna; C1, C2 = clypeal setae; F1 = frontal seta; Fa: pore on the frons; $\mathrm{L} 1$ = lateral seta; $1 \mathrm{~b}=$ labium; $1 \mathrm{p}=$ labial palpus; $\mathrm{M} 1, \mathrm{M} 2$ = mandibular setae; $\mathrm{MD} 1, \mathrm{MD} 2=$ microdorsal setae; $\mathrm{MG} 1=$ microgenal seta $; \mathrm{mp}=$ maxillary palpus; P1, P2 = posteriodorsal setae; S1, S2, S3 = stemmatal setae; $\mathrm{spr}=$ spinneret; SS1, SS2, SS3 = substemmatal setae; stm $=$ stemma. 

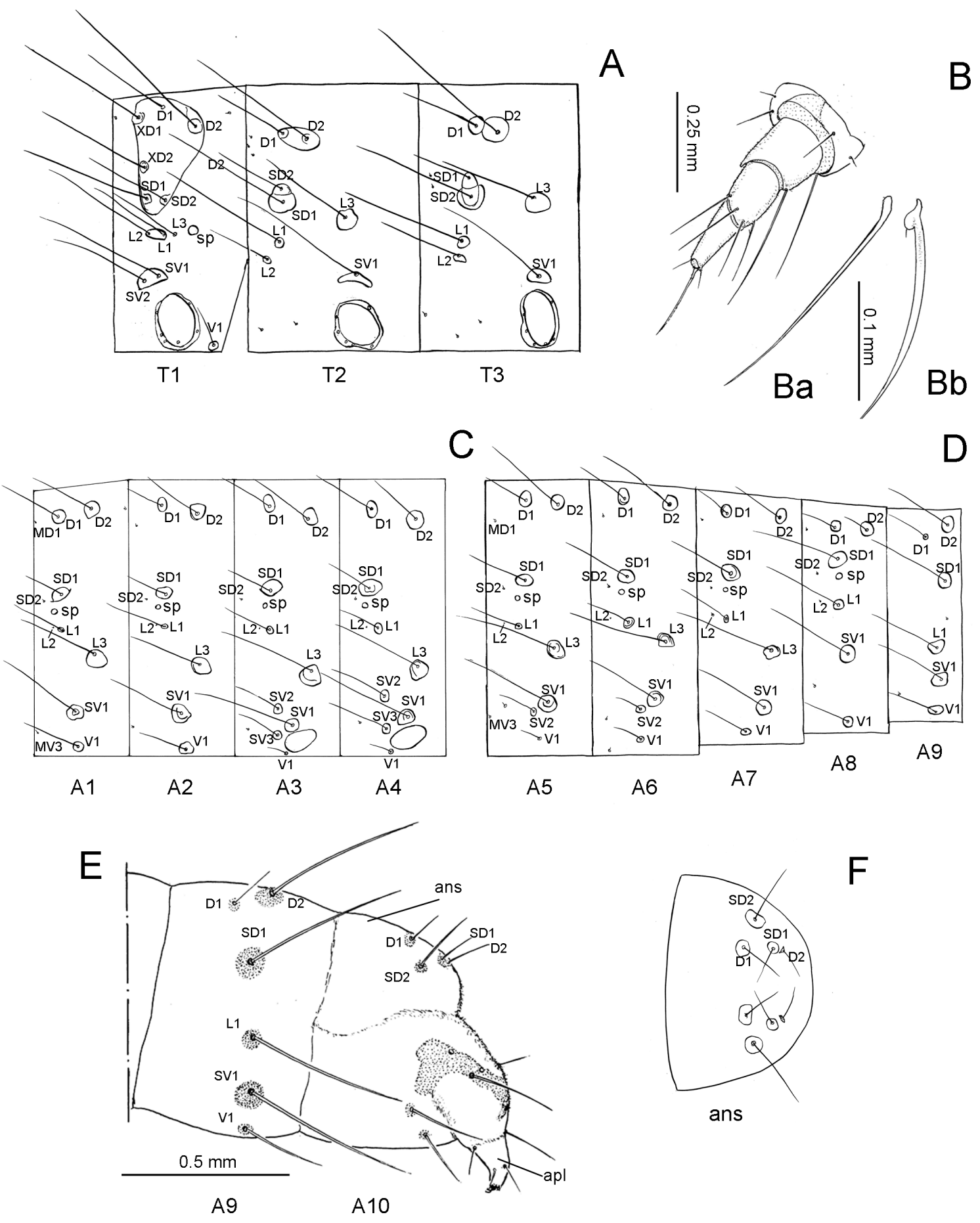

Fig. 6. Mature larval thorax and abdominal segment of Tonza citrorrhoa Meyrick, 1905 (OPU-INLE2018IV0031|SK600, 0025|SK603, 0026|SK604). A. Thorax segment 1-3. B. Thoracic leg on thorax segment 1. C. A 1-4. D. A5-9. E. A9-10. F. Anal shield. Abbreviations: ans = anal shield; apl = anal proleg; $\mathrm{Ba}=$ claw, lateral view; $\mathrm{Bb}=$ same, frontal view; $\mathrm{D} 1, \mathrm{D} 2=$ dorsal setae; $\mathrm{L} 1, \mathrm{~L} 2, \mathrm{~L} 3$ = lateral setae; MD1 = microdorsal seta; MV3 = microventral seta; SD1, SD2 = subdorsal setae; $\mathrm{sp}=$ spiracle; $\mathrm{SV} 1, \mathrm{SV} 2, \mathrm{SV} 3$ = subventral setae; V1 = ventral seta; XD1, XD2 = XD group, dorsal setae on the anterior margin of the $\mathrm{T} 1$. 


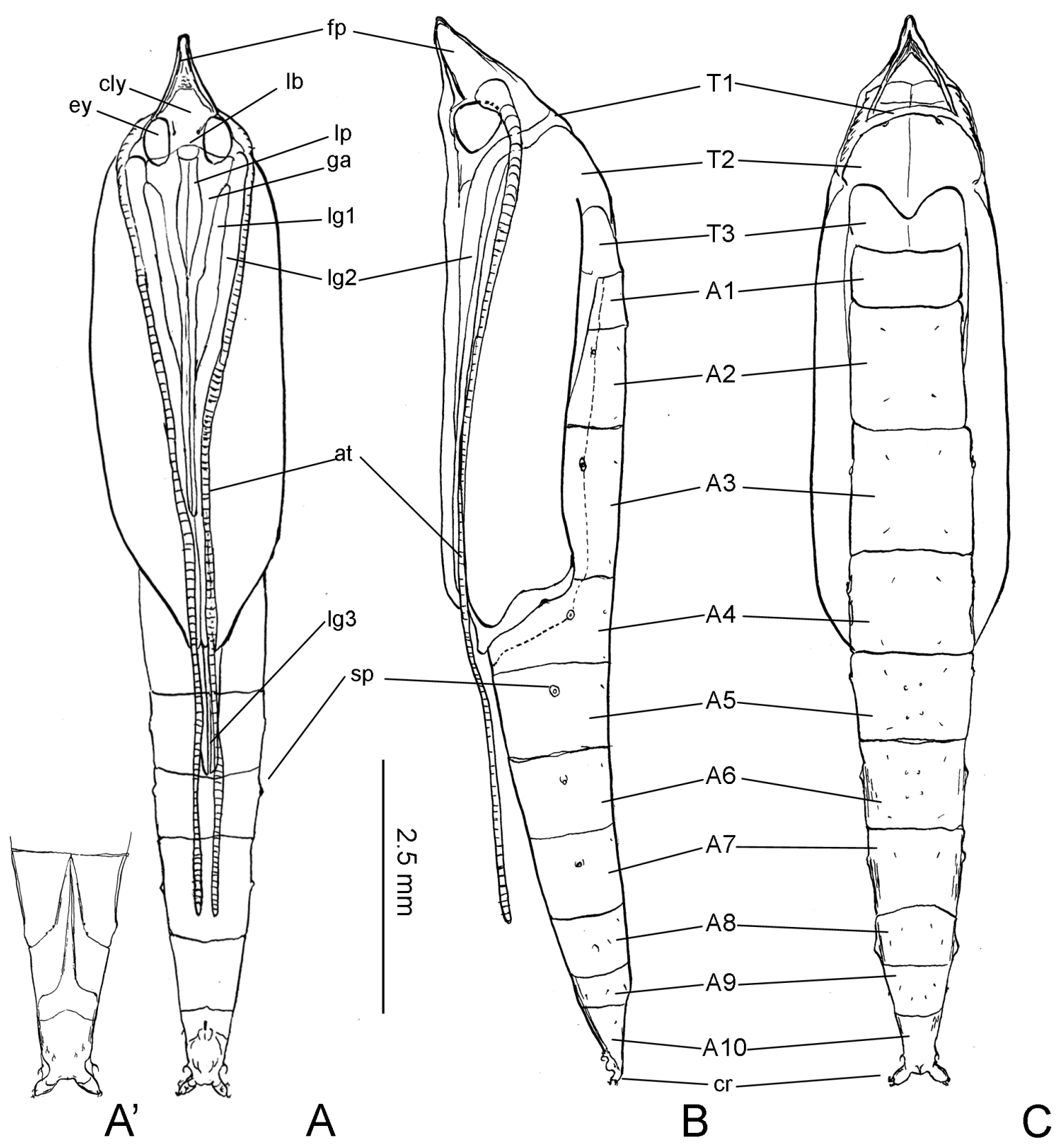

Fig. 7. Pupa of Tonza citrorrhoa Meyrick, 1905 (OPU-IN-LE2018IV0018-0024). A. Male, ventral view. $\mathbf{A}^{\prime}$. A7-10 of female. B. Lateral view. C. Dorsal view. Abbreviations: at $=$ antenna; cly $=$ clypeus; $\mathrm{cr}=$ cremaster; ey = eye; $\mathrm{fp}=$ frontal process; $\mathrm{lb}=$ labrum, labial palpus; $\lg 1=$ foreleg; $\lg 2=$ midleg; $\lg 3$ = hindleg; $\mathrm{pr}=$ proboscis. 

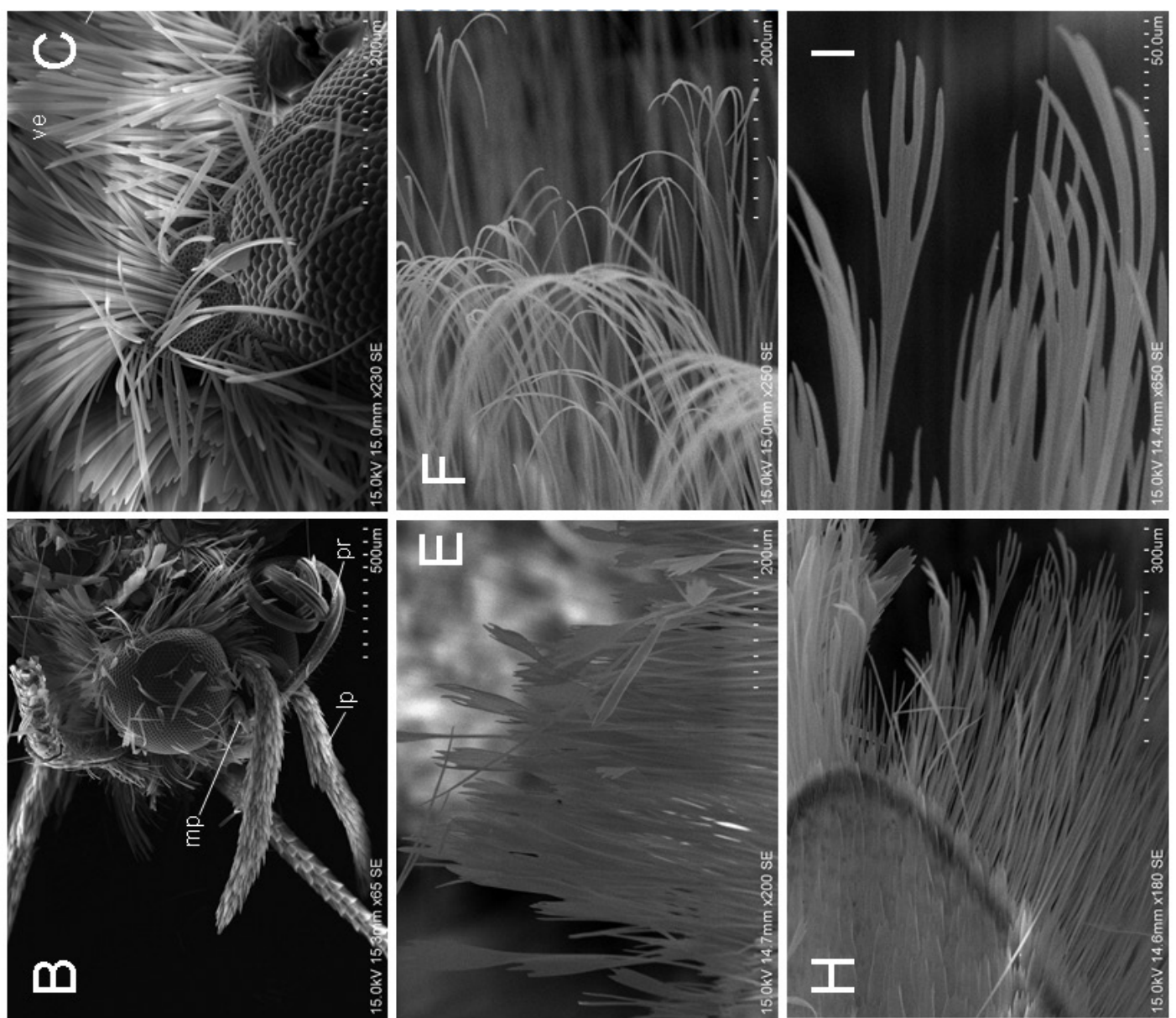

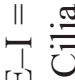

II

๓

过

in

管

m

ชิ

$\sum_{\infty}^{\infty} \cdot \frac{\pi}{0}$

듀

团

它过

ํํㅇ จ

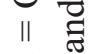

这

$\leq$

ㅇำ

ن

总

$\sum \frac{1}{2}$

:

:

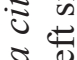

엉

बे

范通
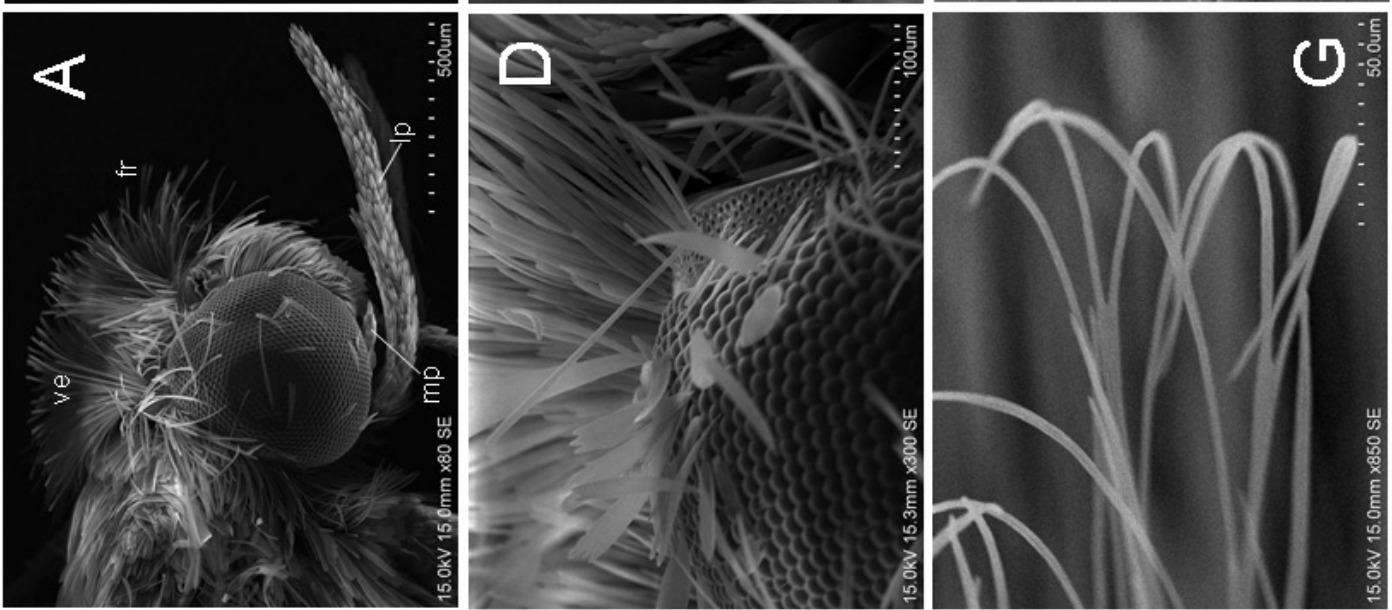

专

$\stackrel{\Xi}{ \pm}$

定部

$\sum_{\text {I }}$ 흥

武

पे

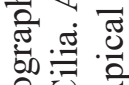

०ण

- Tं

도

ธี

오요

是运

毒

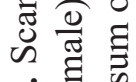

$\infty$ के

방 के 


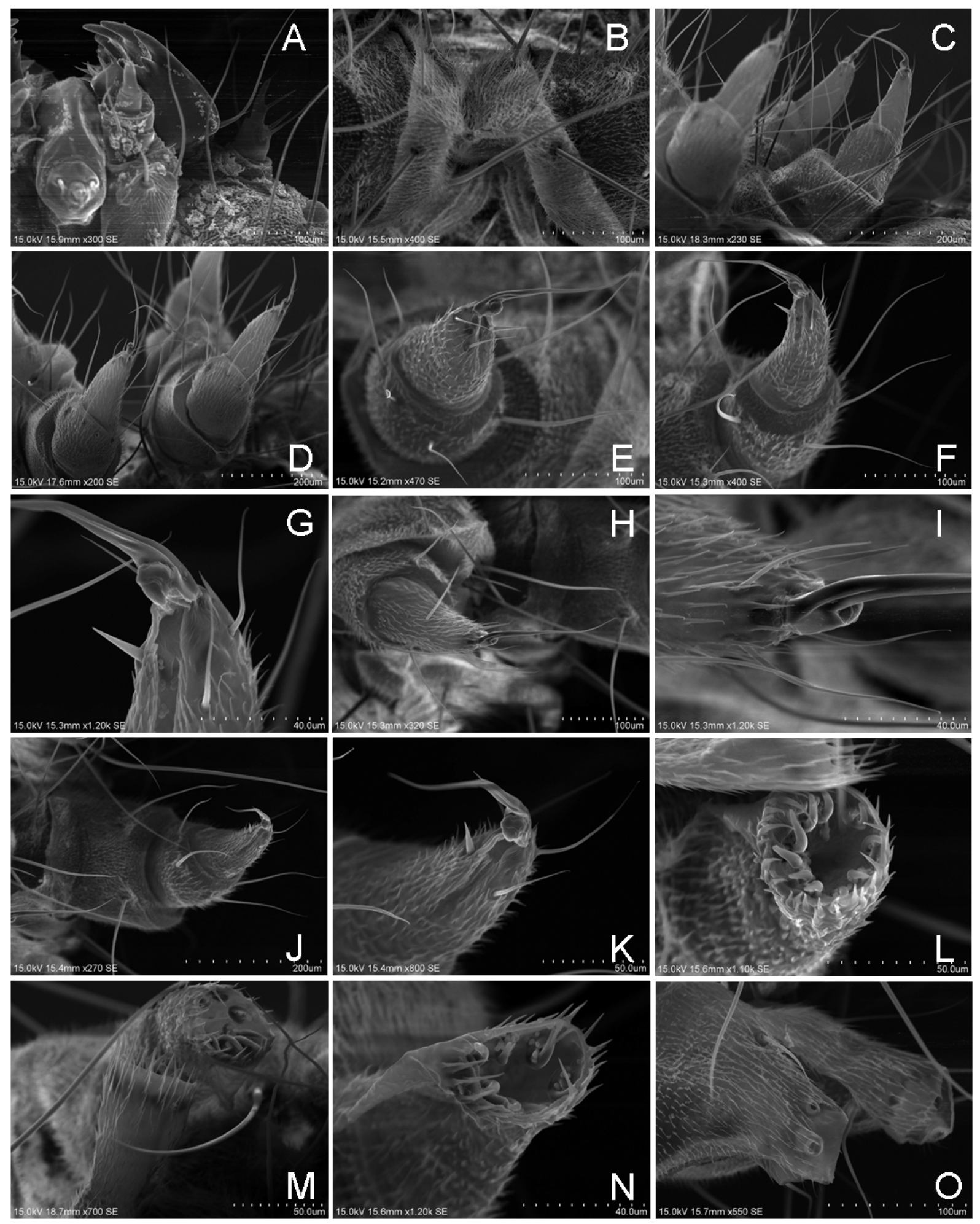

Fig. 9. SEMs of the mature larval structure of Tonza citrorrhoa Meyrick, 1905 (OPU-INLE2018IV0035|SK543). A. Mandible and maxillary palpus. B. Jugular gland-like structure. C. Prothoracic legs. D. Meso- and metathoracic legs. E. Right mesothoracic leg. F. Left mesothoracic leg. G. Same, base of claw. H. Right metathoracic leg. I. Same, base of claw. J. Left metathoracic leg. K. Same, claw and tarsus. L-M. Crochets of proleg on A3. N. Same on A4. O. Crochets of anal prolegs. 

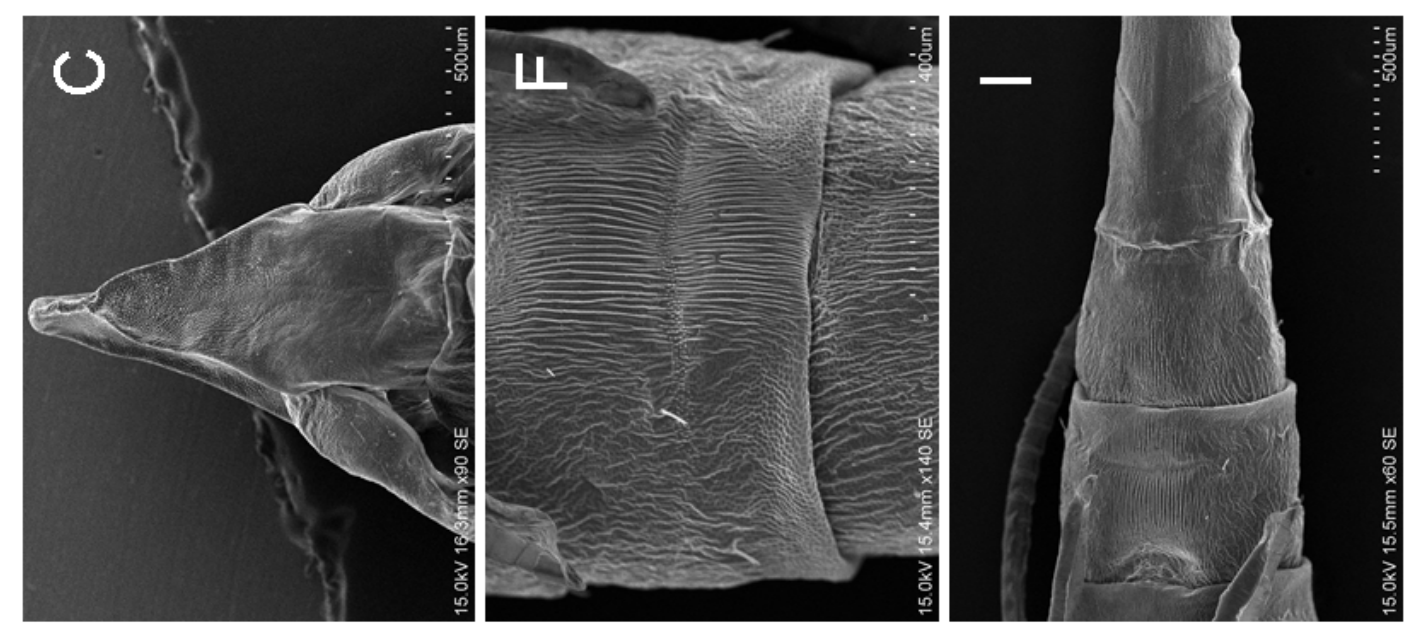

这家

矛
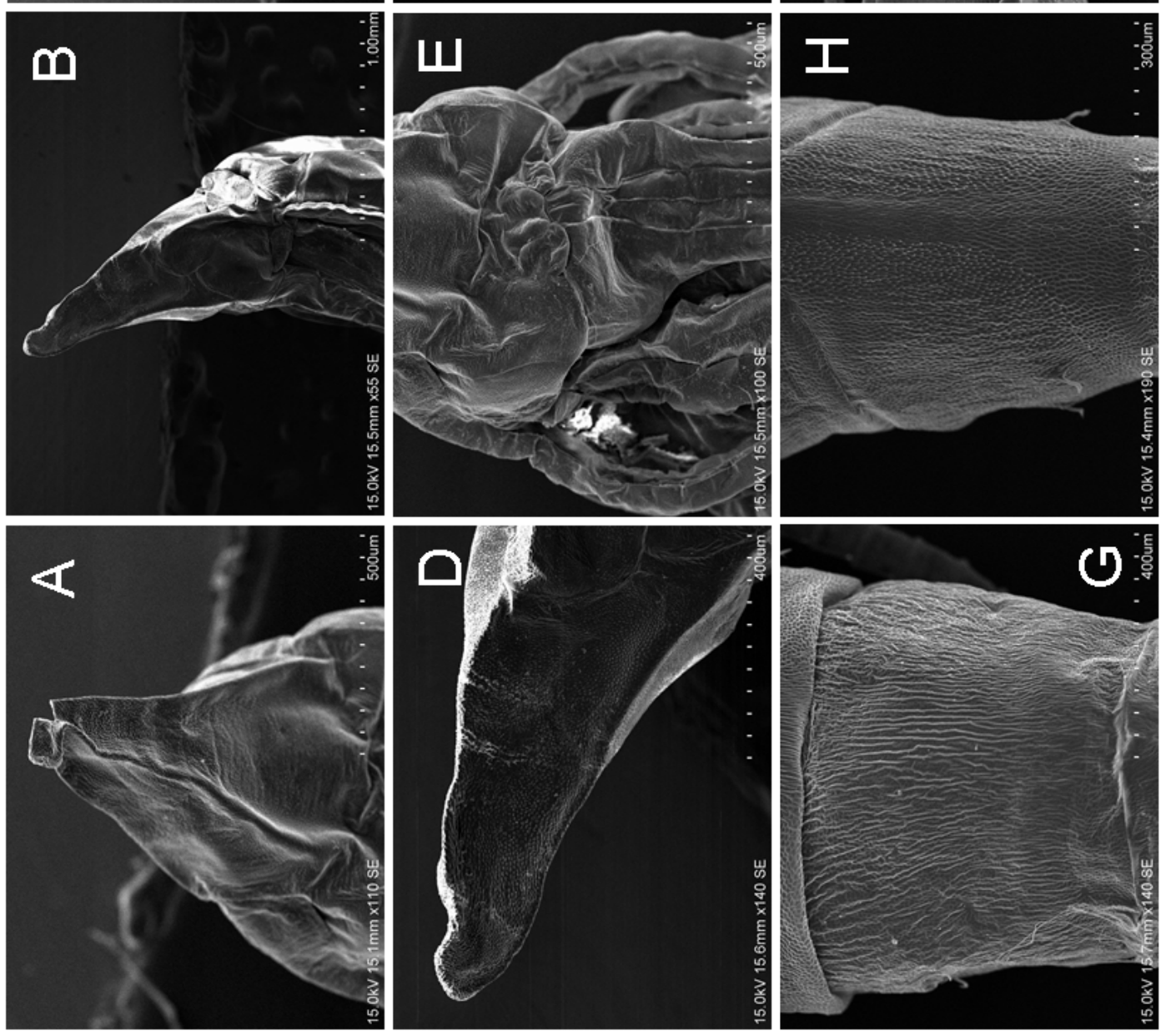

竎

की

는

푤

这

य

穴 $\frac{0}{8}$

章

$\infty$

$\sum_{8}^{\infty}$

$\infty$

고월

完恶

定

(요

동

되

苍

㐫 $\frac{7}{2}$

¿

है

旅

足

है

岩

듀

ㄹํㅇ

윰

त

ర

ส

चु

흘

恵它

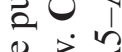

总年

$4:$

舟苞市

至壱 巳

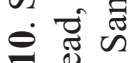

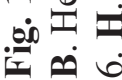



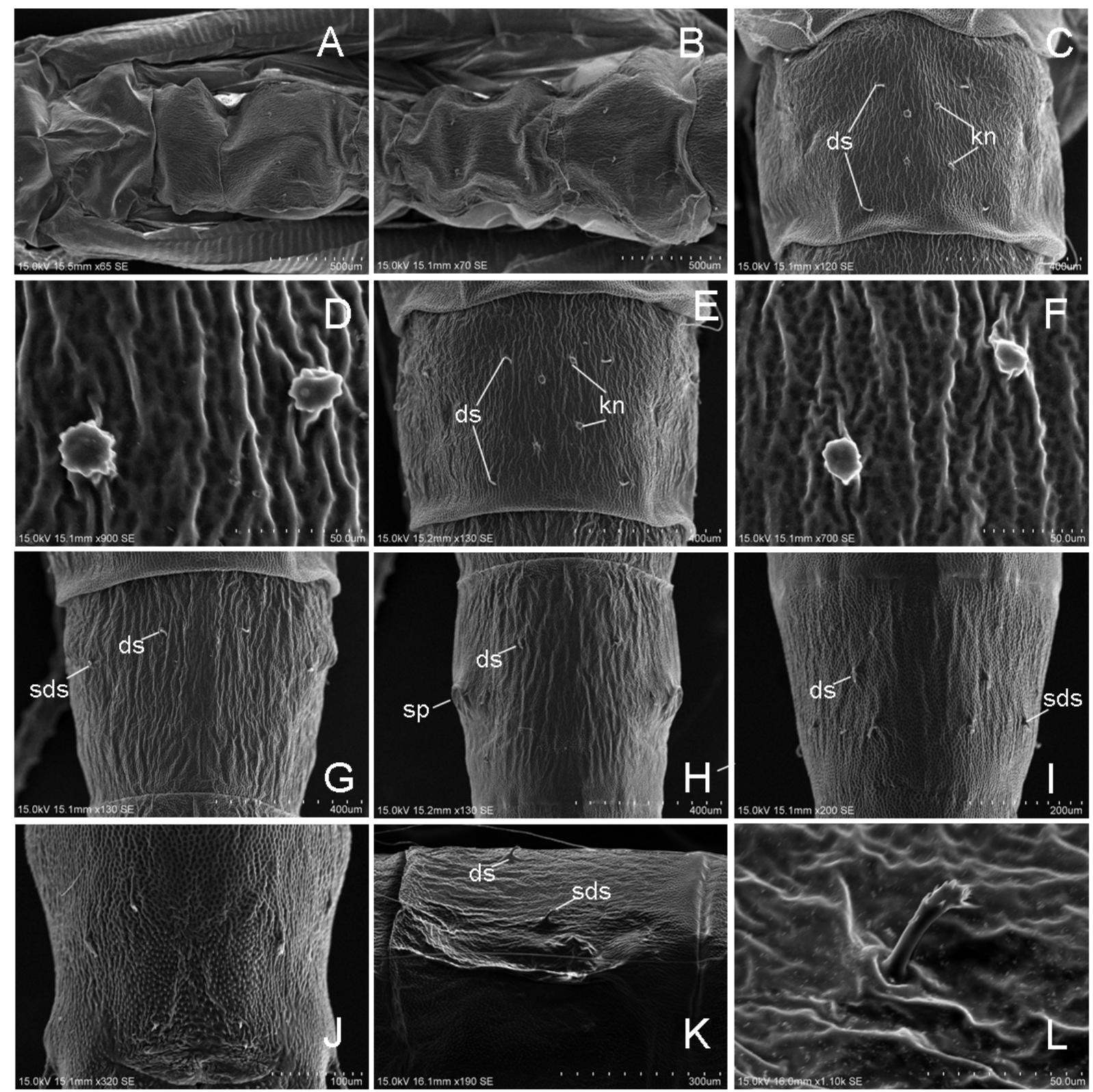

Fig. 11. SEMs of pupal abdomen of Tonza citrorrhoa Meyrick, 1905 (OPU-IN-LE2018IV0018 -0020). A-J. Dorsal view. K-L. Lateral view. A. A1-A2. B. A3-A4. C. A5. D. Anterior two minute knobs on A5. E. A6. F. Anterior two minute knobs on A6. G. A7. H. A8. I. A9. J. A10. K. A10. L. Subdorsal seta of A10. Abbreviations: $\mathrm{ds}=$ dorsal seta; $\mathrm{kn}=\mathrm{knob}$; $\mathrm{sds}=$ subdorsal seta; $\mathrm{sp}=$ spiracle. 

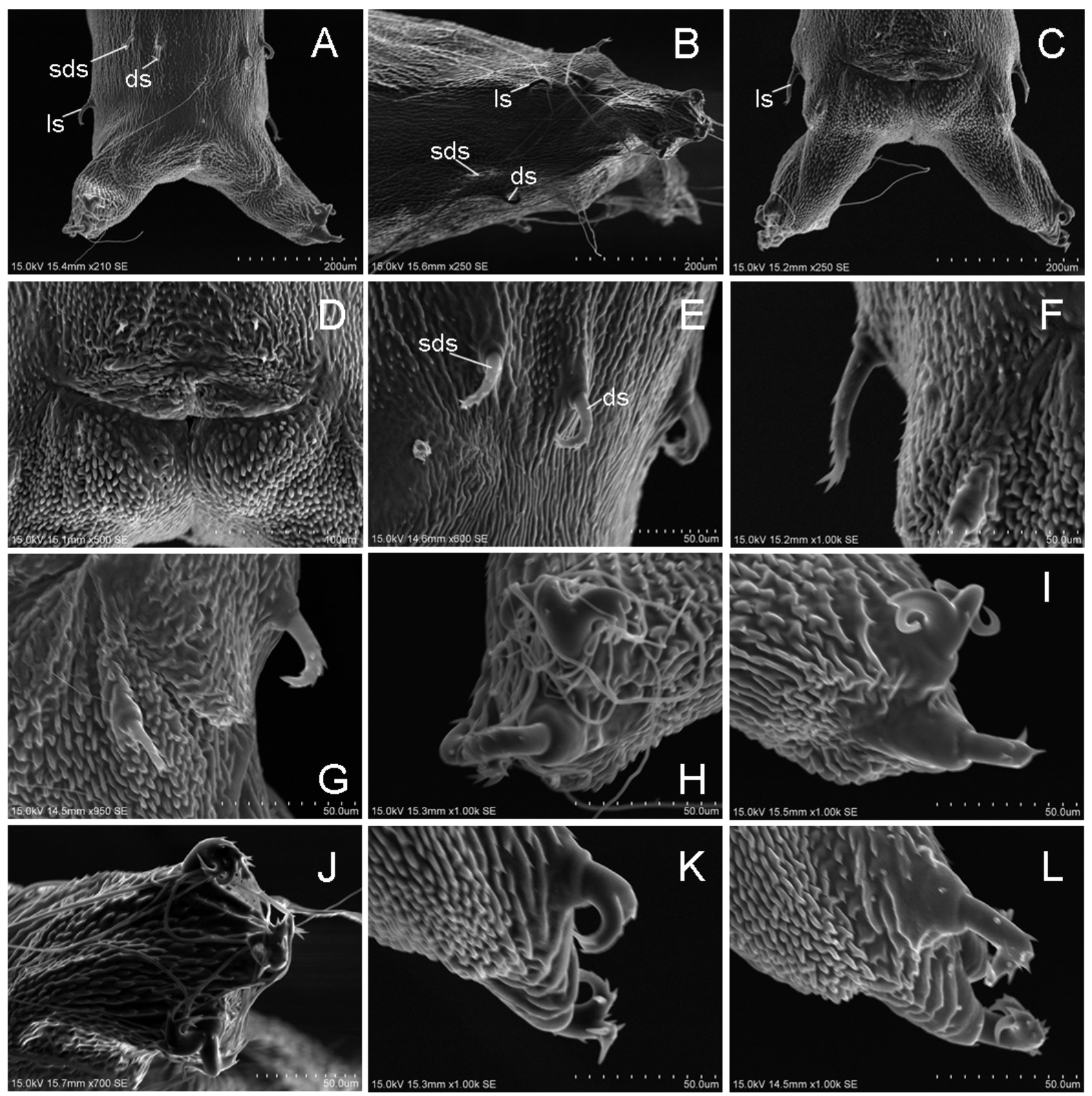

Fig. 12. SEMs of pupal abdominal segments A9-A10 of Tonza citrorrhoa Meyrick, 1905 (OPU-INLE2018IV0018 -0020). A. Ventral view. B. Lateral view. C. Dorsal view. D. Middle portion of A10. E. Ventral setae of A9. F. Lateral seta of A10. G. Dorsal setae of A10. H. Apical setae of right process of cremaster, ventral view. I. Same, left process. J. Left process of cremaster, lateral view. K-L. Apical setae of right process of cremaster, dorsal view. Abbreviations: ds = dorsal seta; $1 \mathrm{~s}=$ lateral seta; $\mathrm{sds}=$ subdorsal seta; svs $=$ subventral seta; vs $=$ ventral seta. 


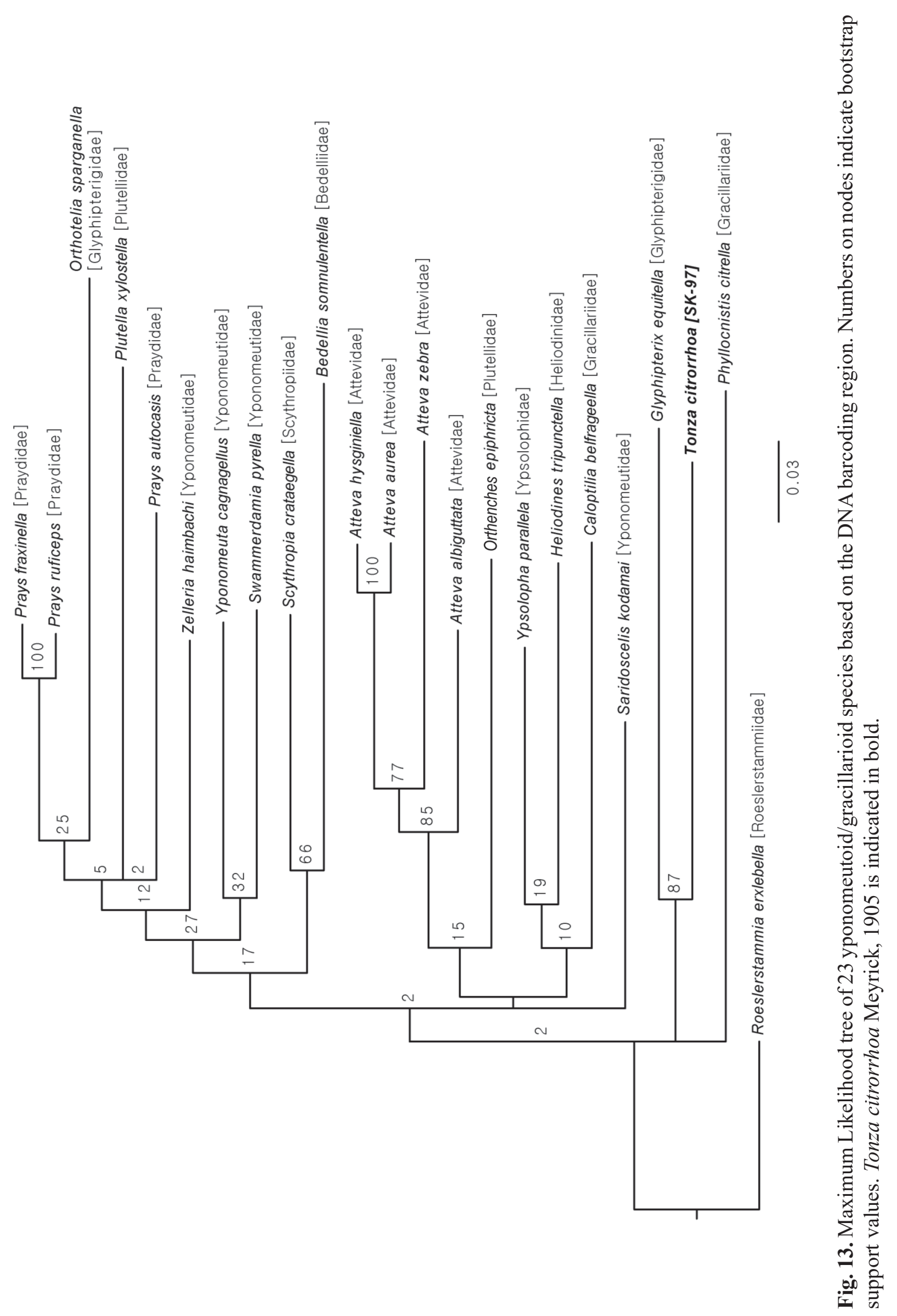


KOBAYASHI S. et al., Designation of a new family group name, Tonzidae fam. nov.

rolled on ventral side; three pairs of spiny hooked setae from apex of caudal processes (Fig. 12), the hook furcate as a pair of W-shaped spines with numerous minute spines (Fig. 12G-L).

Genus Tonza Walker, 1864

Tonza Walker, 1864: 1011 - Kobayashi et al. (2015: 68-69) (redescription). Type species: T. purella Walker, 1864.

\section{Diagnosis}

For the adult: see description for the family and see Kobayashi et al. (2015).

\section{A checklist and distribution of the species of the genus Tonza}

1. Tonza purella Walker, 1864

\section{Distribution}

Australia (Queensland; Moreton Bay, type locality; specimens including types in NHMUK and data on BOLD; Bold Index Number (BIN), BOLD:AAY2226).

\section{Hostplants}

Unknown.

2. Tonza citrorrhoa Meyrick, 1905

\section{Distribution}

India; Sri Lanka; China (Taiwan); Japan (Kagoshima, Okinawa); Indonesia, identity not certain; Philippines, identity not certain (Specimens in NHMUK, but not including the two syntypes, whereabouts unknown; USNM and data on BOLD).

\section{Hostplants}

Putranjiva matsumurae, Putranjivaceae Endl. (present study).

3. Tonza callicitra Meyrick, 1913

\section{Distribution}

Solomon Islands (Bougainville; type locality, types in NHMUK), New Guinea, New Ireland, New Britain, E. Sula: Mangole, Salomo Archipelago (Shortland I.).

\section{Hostplants}

Unknown.

\section{Note}

The genus is also found fairly widely in the palaeotropics, as well as in Indo-Australasia, in Africa, Madagascar (material in NHMUK and data on BOLD; BOLD:ACU1104) and on Réunion (J. Rochat \& M. Bippus, pers. comm.). 
Tonza citrorrhoa Meyrick, 1905

Figs 1-13

Tonza citrorrhoa Meyrick, 1905: 614 - Heppner (1992: 74) (species list) - Kobayashi et al. (2015: 69-72, figs 1-2).

\section{Diagnosis}

See Kobayashi et al. (2015: 69) and diagnosis of the family.

\section{Material examined $(4 \hat{\partial} \hat{\partial}, 7 \stackrel{+}{q}, 10$ unsexed)}

JAPAN: $2 \widehat{\jmath}, 5 q q$ adults, Ryukyus, Okinawa Prefecture, Mt. Kubura-dake, Yonaguni Is., 3-6 May 2016, M. Kimura leg. (host: Putranjiva matsumurae), 22 Apr. 2016 (larva) (OPU-IN-LE2018IV0003-0009); material in NHMUK, see above, has not been critically re-examined; $2 \hat{\jmath} \widehat{\partial}, 2$ q $q$, 3 unsexed, pupae, same data as for preceding, but May 2016 (OPU-IN-LE2018IV0018-0022); 7 unsexed larvae, same data as for preceding, but May 2016 (OPU-IN-LE2018IV0026-0028|SK600, 0025|SK603, 0026|SK604, 0035|SK543(exuvia)).

\section{Type locality}

SRI LANKA: Hantane.

\section{DNA barcodes}

GenBank accession no. LC310893, voucher no. SK-097. BIN: BOLD:ACX8102, voucher no. USNMENT00657266.

\section{Additional description}

ADULT. Wingspan range 11.0-14.4 mm (mean $13.7 \mathrm{~mm}, \mathrm{n}=9$ ): forewing length range $5.2-7.1 \mathrm{~mm}$ (mean $6.6 \mathrm{~mm}, \mathrm{n}=9$ ).

Male genitalia And female Genitalia. See Kobayashi et al. (2015: fig. 2).

Mature Larva (Figs 4-6, 9). Range: $11.5-12.5 \mathrm{~mm}$ in length (mean $12.0 \mathrm{~mm}, \mathrm{n}=4$ ). Integument varying from yellowish green to yellow in colouration, full mature larva yellow in colouration, marked with numerous purple blotches and white dots (Fig. 4). Pinacula conspicuous, dark brown in colouration (Fig. 4A, J). Primary setae long and secondary setae absent (Fig. 4A-E).

HEAD (Fig. 5). Hypognathous. Head capsule marked with numerous ochreous spots (Fig. 5A, C), 0.90 $1.00 \mathrm{~mm}$ in width (mean $0.94 \mathrm{~mm}, \mathrm{n}=5$ ). Frontclypeus wide, extending a half to epicranial notch. Mandible about $0.15 \mathrm{~mm}$ in length, with three large teeth, two smaller teeth, and three small teeth at inner portion, with M1 and M2 setae much shorter (Fig. 5F). Six stemmata arranged in an arc except for S1 and S6; S1 more posterior and S6 ventrad (Fig. 5A-C).

Cranial setae (Fig. 5A-C). MD1 very long; A1, A2 and A3 as obtuse triangle with A2 most distant from stemmata; P1 below Af2-P2 line; pore not found.

Thorax (FIG. 6A-B). T1 shield indistinct, yellow in colouration, marked with dark brown patches. Jugular gland (adenosma) absent, but like structure present ventrally on T1 (Fig. 4F), anterior to the legs and antero-medial to the long setae SV1 and SV2; the structure not eversible and a tubular or sacciform gland at inner side of body not found. D1 and D2 approximated on T2 and T3; SD1 and SD2 approximated on T2 and T3; L-group trisetose, L1 and L2 on the same pinacula on T1 and separated on T2 and T3; SV1 and SV2 on the same pinacula on T1 and on separate pinacula on T2 and T3; Seta V1 
KOBAYASHI S. et al., Designation of a new family group name, Tonzidae fam. nov.

present on T1, absent T2 and T3. Thoracic legs pale ochreous to brown in colouration; pale brown claws elongate, slightly curved to inner side (Figs 4F, 6B).

Abdomen (Fig. 6C-F). D1 above level of D2 except for A9; SD2 very small, separated from pinaculum of SD1; L-group trisetose on A1-7, bisetose on A8 and unisetose on A9; L2 minute; SV-group trisetose on $\mathrm{A} 3$ and $\mathrm{A} 4$, bisetose on $\mathrm{A} 5$ and $\mathrm{A} 6$, unisetose on A1, A2, and A7-A9; Seta D1 of A9 segment markedly more slender than D2. Anal shield indistinct as in figure 6F. Prolegs present on A3, A4, and A10 (Fig. 4A, G). Ventral prolegs elongate, about $2 \times$ length of width of proleg base; crochets uniordinal, arranged in a circle, being usually 12 in number (Figs $4 \mathrm{H}-\mathrm{I}, 9 \mathrm{~L}-\mathrm{N}$ ). Crochets of the anal prolegs arranged in a semicircle (Fig. 4K).

PuPA (Figs 7, 10-12). General: long and slender, yellowish green in colouration, 10-11 mm in length, 1.0-2.0 mm in diameter. Maxillary palpi concealed (Fig. 10E). Dorsum of A2-A9 with two pairs of minute spiny setae from dorsal side (Figs 7B, C, 11). Other characters as for family diagnosis.

\section{Distribution}

INDIA: Khasia/Khasi Hills; Darmsala, Punjab; Coimbatore (NHMUK): new record. SRI LANKA: Colombo, Kandy, Bogawantalawa, Puttalam, Maskeliya, Bentota, Gulla, Dondanduwa, Hikkaduwa, Nawalatipiya (NHMUK): new record, Hantane [Hanthana] (Meyrick 1905). CHINA: Taiwan (Heppner 1992; USNM, on BOLD). JAPAN: Kagoshima Prefecture: Amai-Ohshima Is. (Seino 2016), Okinawa Pref.: Okinawa Is. (Kobayashi et al. 2015), Iriomote Is. (Umetsu 2016), Yonaguni Is.: [new record]. INDONESIA: Telawa, Java (NHMUK; abdomen missing, identity not certain but included among 13 identified specimens constituting Meyrick's collection); Sulawesi (NHMUK), identity not certain. PHILIPPINES (NHMUK): identity not certain.

\section{Hostplants}

Putranjivaceae: Putranjiva matsumurae: new larval hostplant record. The adult has been recorded feeding on 'Marygold flowers' [sic; Tagetes L., Asteraceae Bercht. \& J. Presl] at Coimbatore, S. India (NHMUK).

\section{Life history}

The detailed biology of this species is unknown. The third author (Kimura) observed a number of late instar larvae on the young leaves of Putranjiva matsumurae. The larva is a leaf webber tying together several leaves loosely with silk threads (Fig. 3A-C). The full grown larva is suspended from the tree by a silk lifeline spun out from the head spinnerets. Pupation takes place at the intersection of some cross silken threads (Fig. 3H). A number of the mature larvae occurred on tall trees of the hostplant in Yonaguni Is., Okinawa Pref. (Fig. 3A). Young larvae were not found in our study. Given that no larval mine was observed, the young larvae are probably external feeders like the later instars.

\section{Remarks}

The resting posture of the adult moth with head end lowered and abdomen lifted is similar to certain Argyresthiidae, Ypsolophidae and several genera in Yponomeutidae (Fig. 1B). However, when at repose in nature the suspension may be different and rather unusual involving only the prothoracic and mesothoracic legs in contact with the lower surface of a leaf with the wing and body tending to hang vertically below a leaf. In this position, the antennae relatively long with respect to wing length may accentuate a potential false head-like appearance.

Leaf webbing larvae occur in several yponomeutoid families, Yponomeutidae, Scythropiidae, Plutellidae, Ypsolophidae (Ypsolophinae) and Attevidae (Sohn et al. 2013). However, larvae of Tonza form rather 

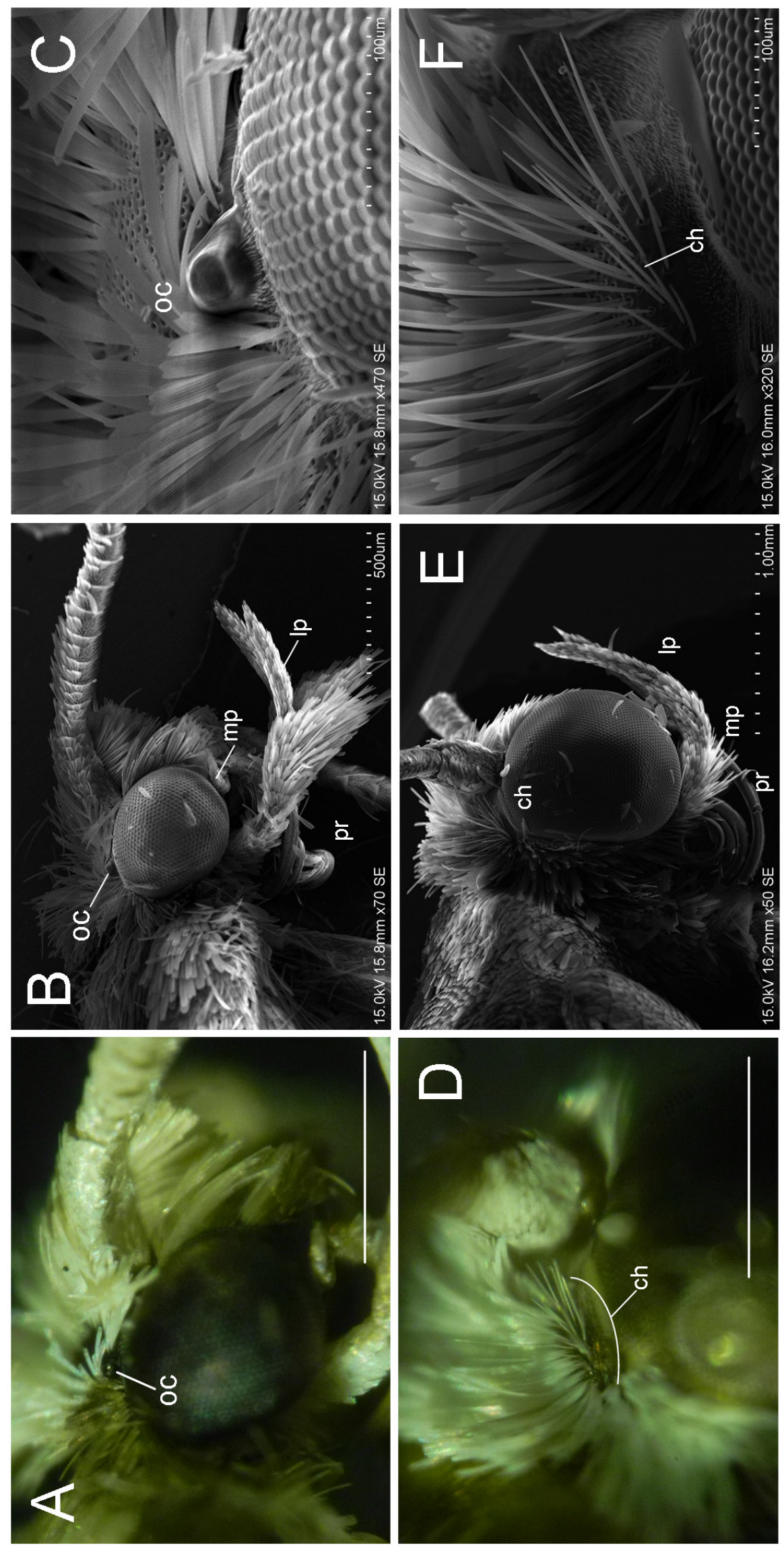

地

a

촗

हैํํㅇ

ब्धे

冚

总

응

응

$\sum_{\infty}$

공

ㅇํㅇ

当记

0.0

○.

只 $\frac{0}{\pi}$

펑

กิ

च

踏。

ஏ ⿷匚⿳丨コ丨

ปิ

है।

दें

ㅡㅇ

水

ن ్ㅡㄹ

《貌

류 를

过总

守

웅

응 छ

$\geqslant$ in

응 긍

फ

즐

๖

틀응

远

$\therefore$ क 0

我密离 
KOBAYASHI S. et al., Designation of a new family group name, Tonzidae fam. nov.

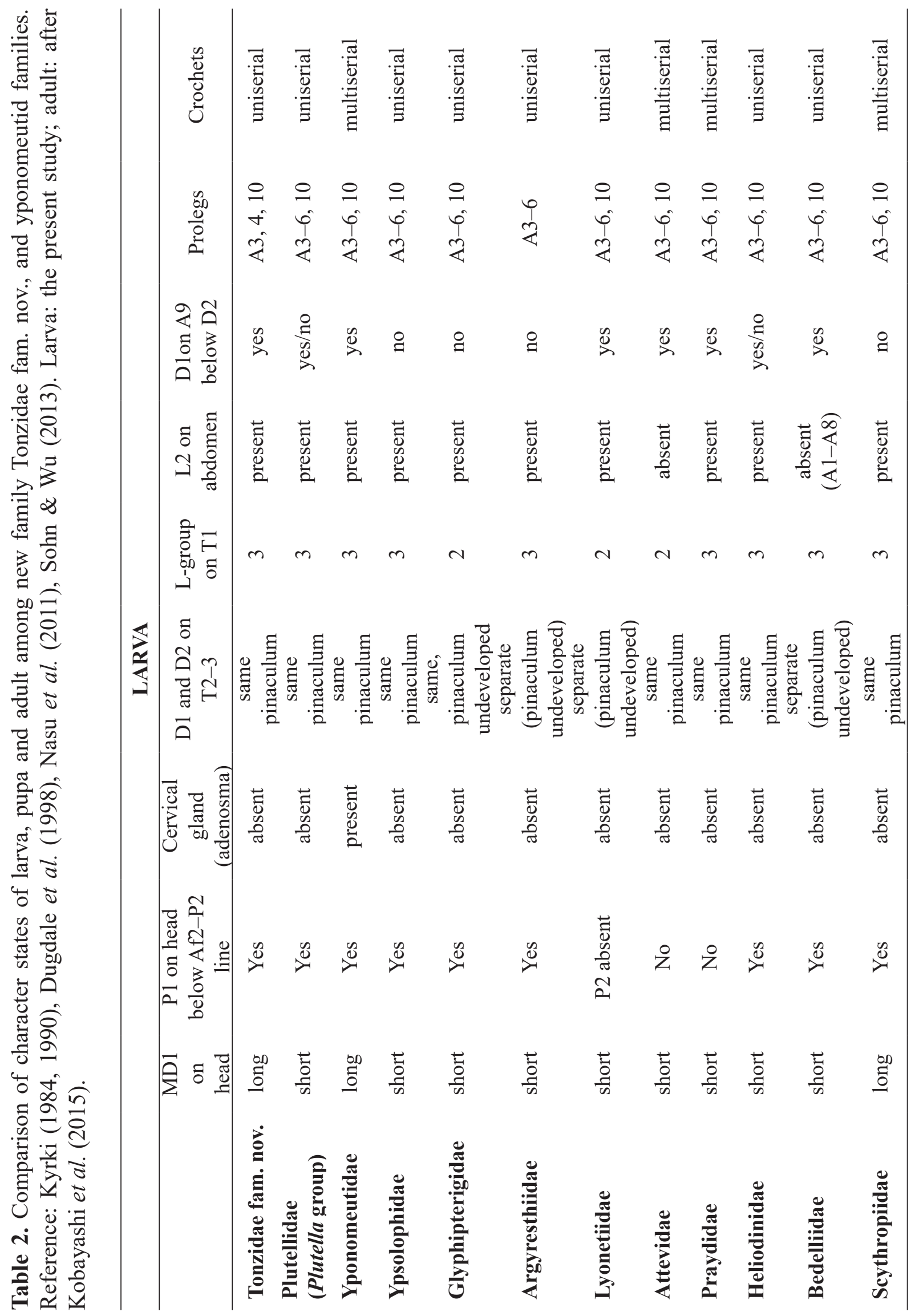




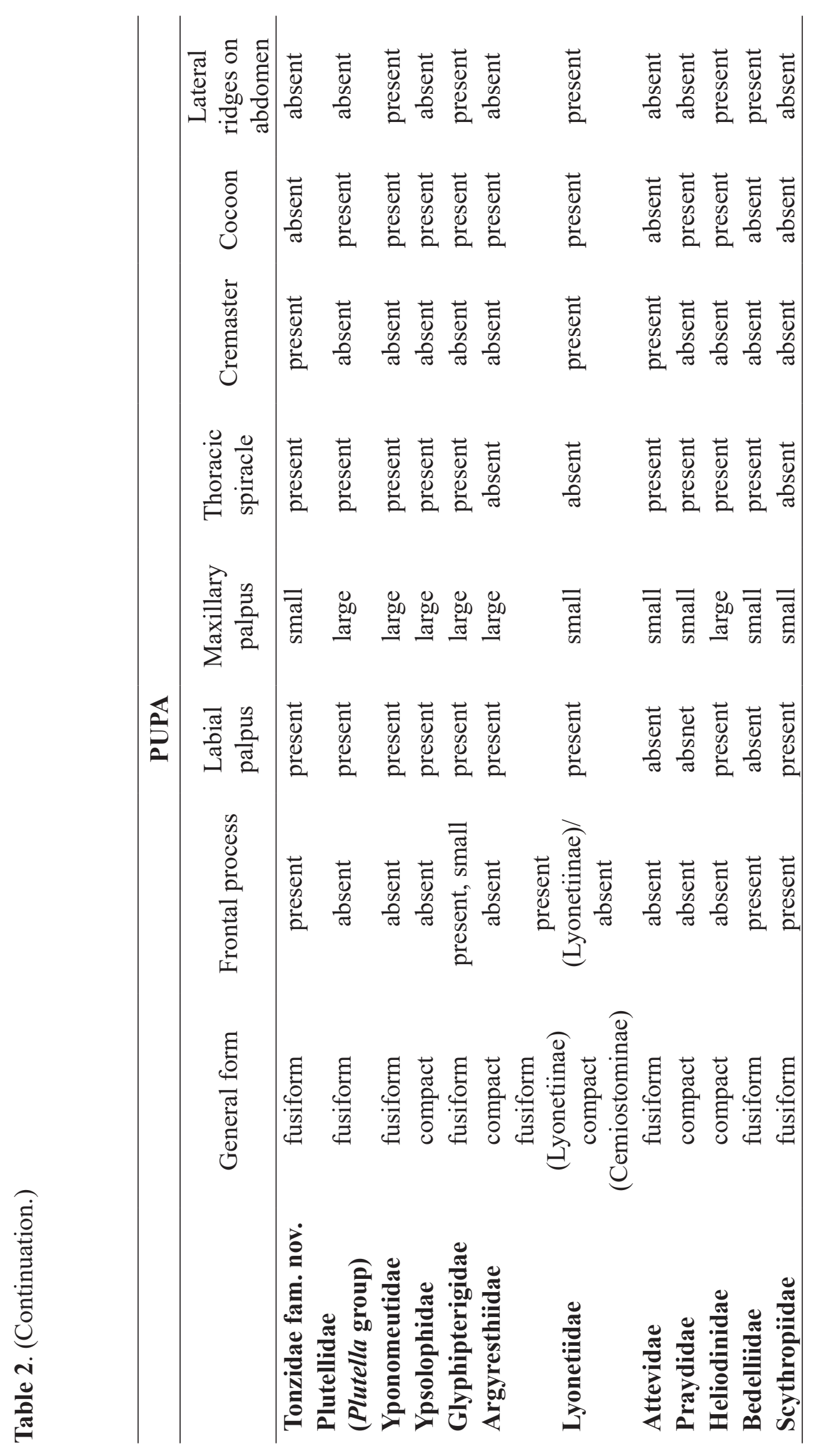




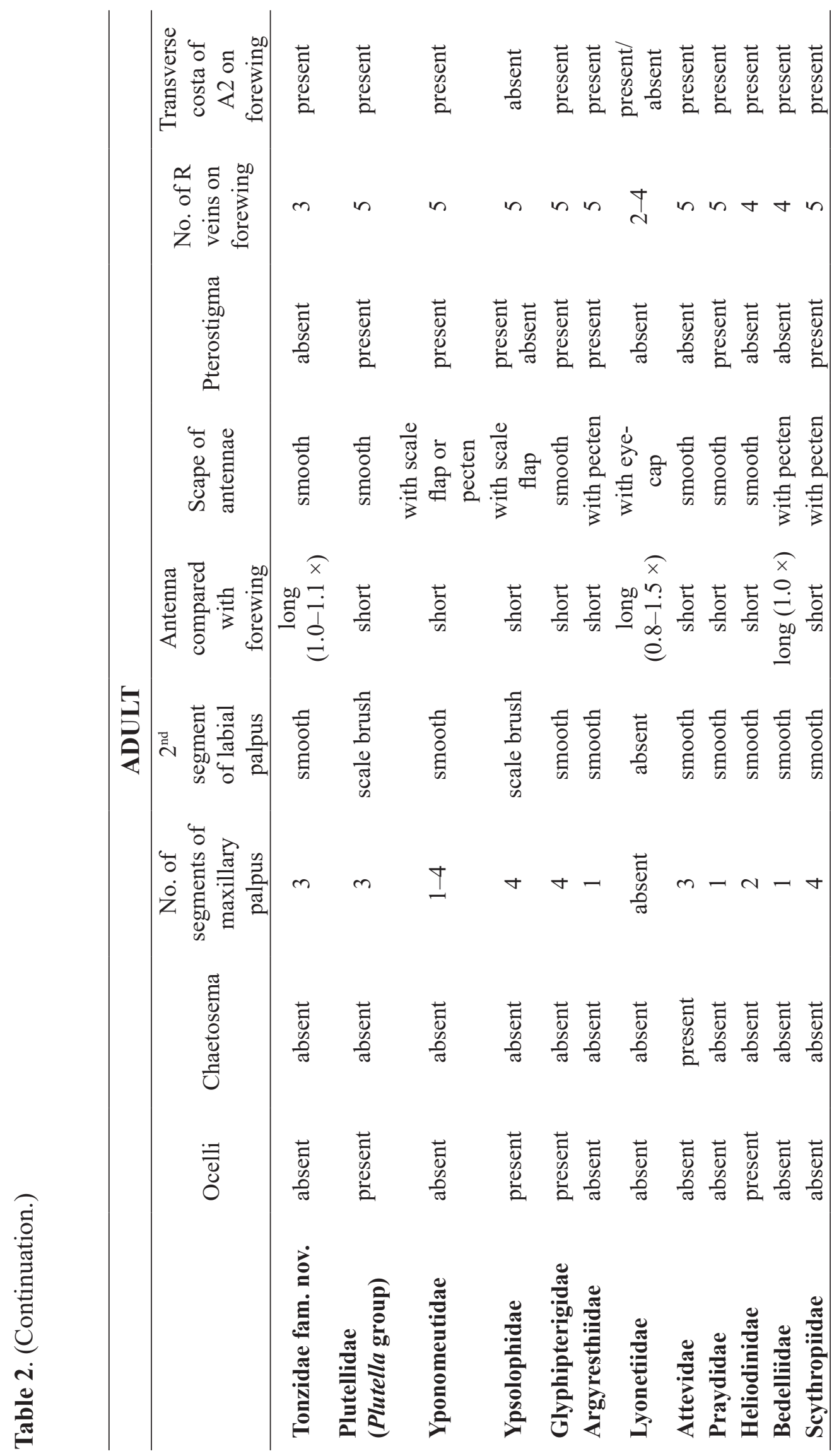




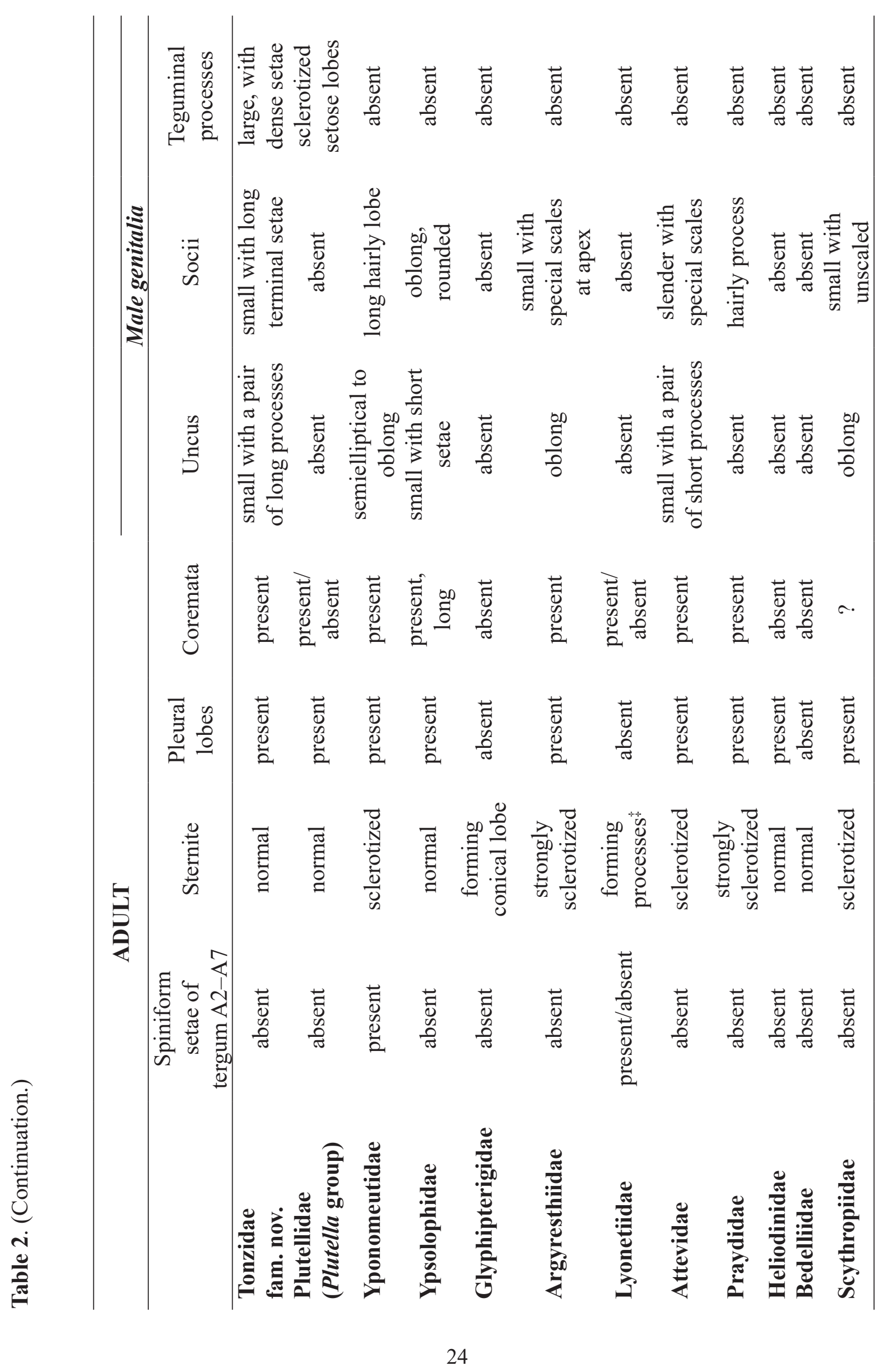




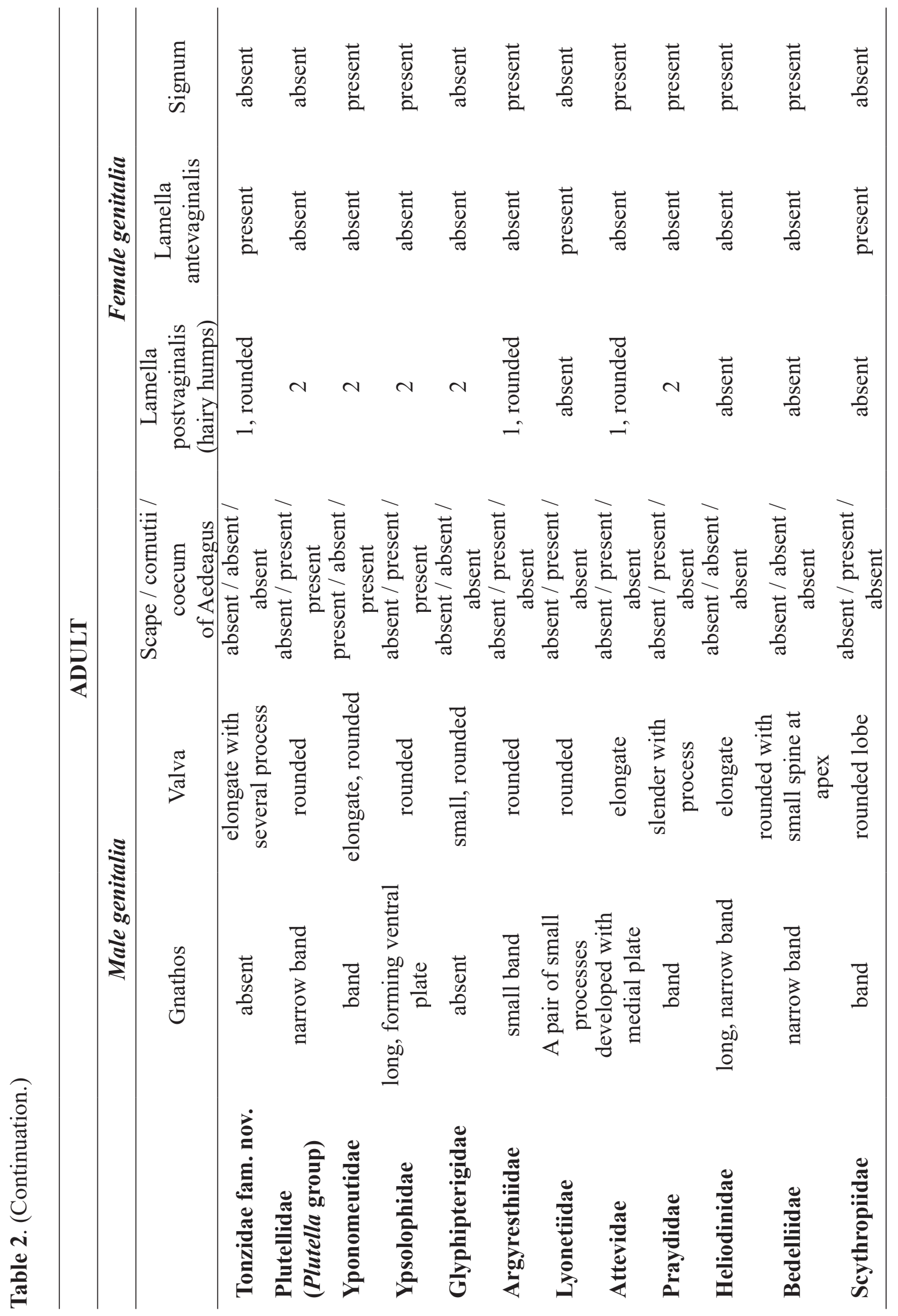



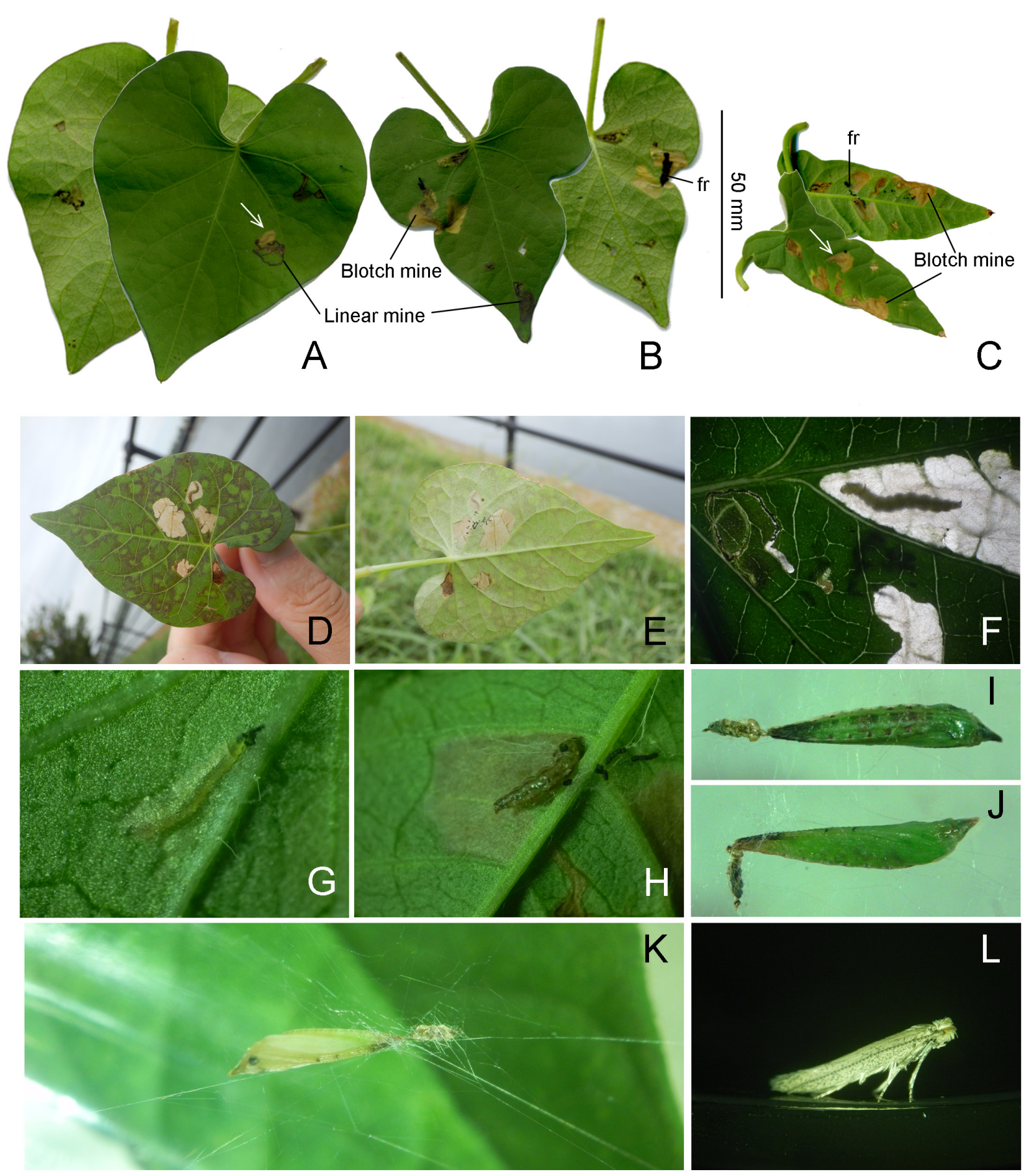

Fig. 15. Biology of Bedellia somnulentella Zeller, 1847, Bedelliidae Stainton, 1849, and its hostplants. A-B, D-L. Ipomoea sp. C. Calystegia sp. A-C. Leaves and mines. D. Blotch mines by later larva. E. Blotch mines and frass on abaxial side of leaf. F. Young larva and later larva. G. Later larva. H. Later larva forming new mine. I. Pupa, dorsal view. J. Lateral view. K. Pupa at the joint of some cross silken threads. Abbreviations: $f r=$ frass. 

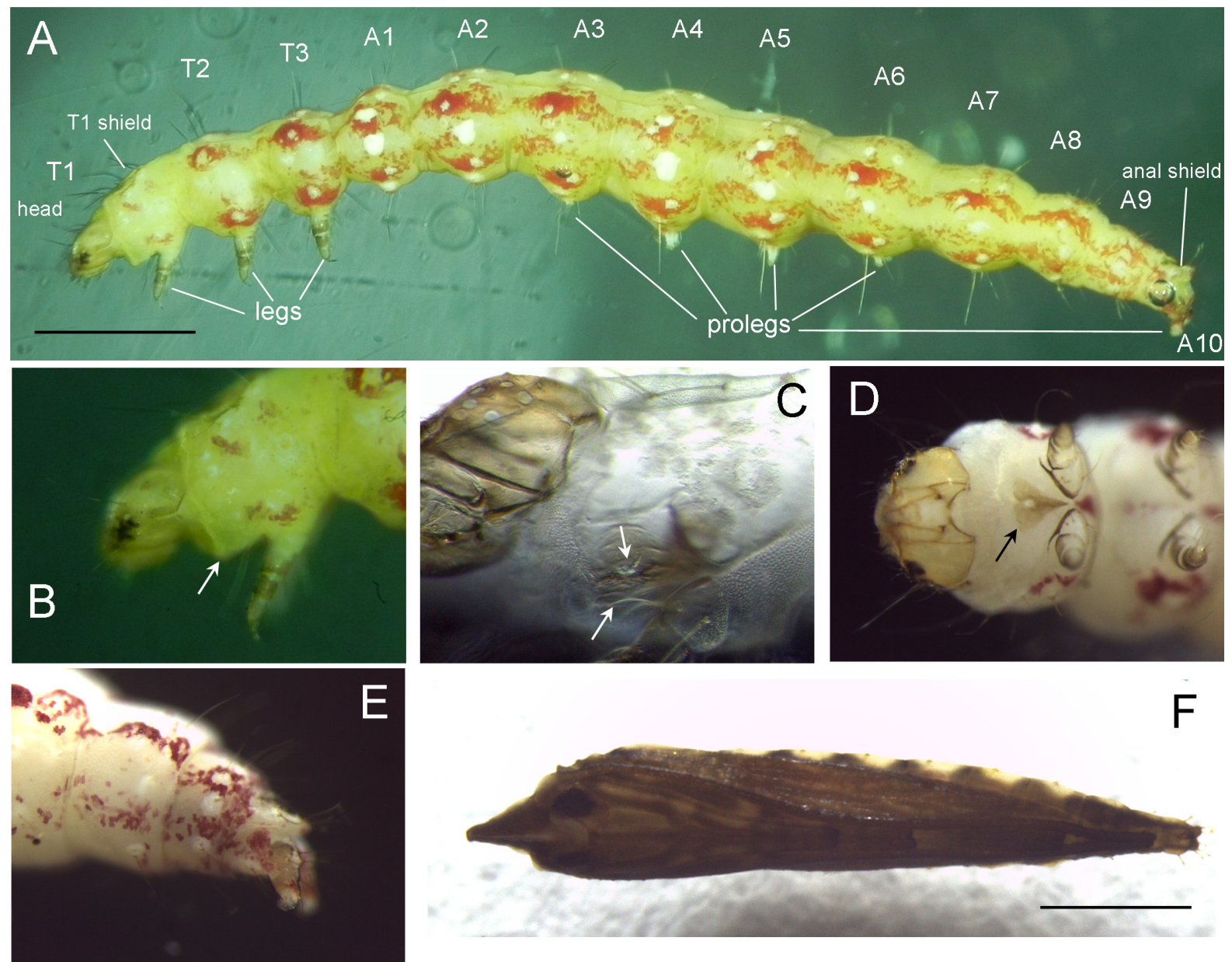

E

$\mathrm{F}$
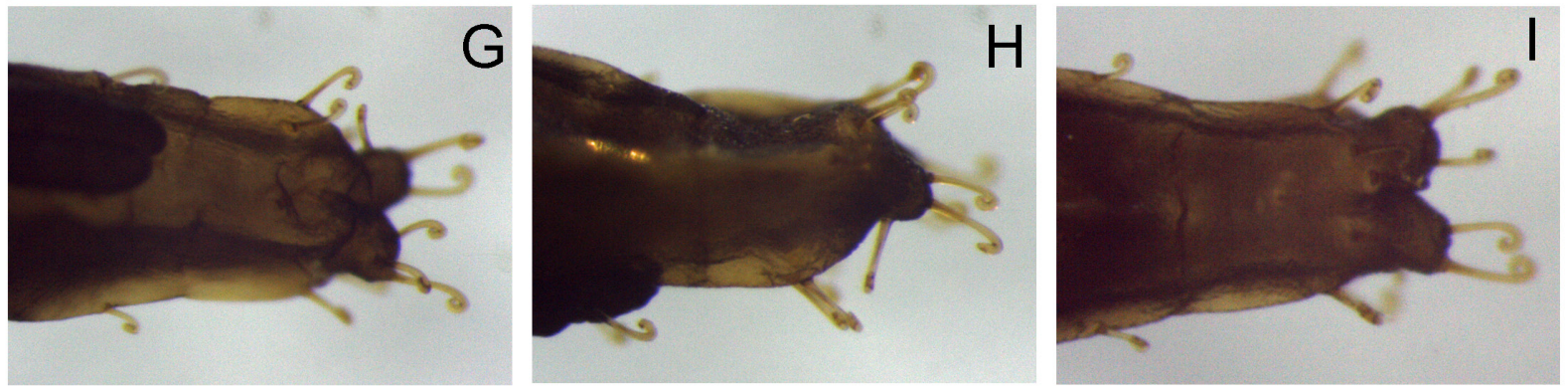

Fig. 16. Mature larva and pupa of Bedellia somnulentella Zeller, 1847. A-E. Mature larva (OPU-INLE2018IV0031|SK612, 0032|SK613). F-I. Pupa (OPU-IN-LE2018IV0038-0039). A. General, lateral view. B. Head and thorax, lateral view. C. Jugular gland-like structure, lateral view. D. Head and thorax, ventral view. E. A8-A10, lateral view. F. General, ventral view. G. Setae of A8-A10, ventral view. H. Lateral view. I. Dorsal view. Scale bars: $1 \mathrm{~mm}$. 

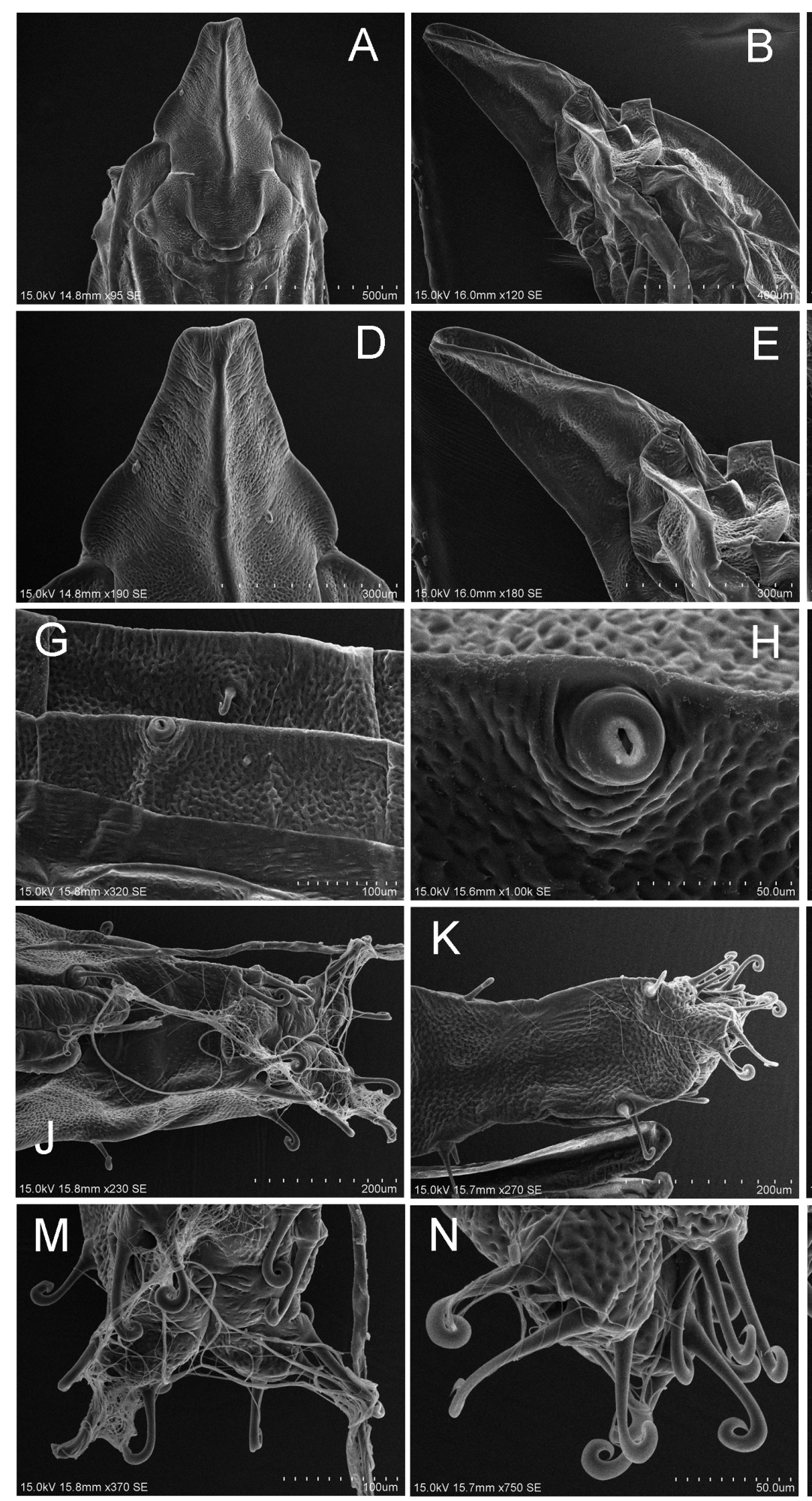
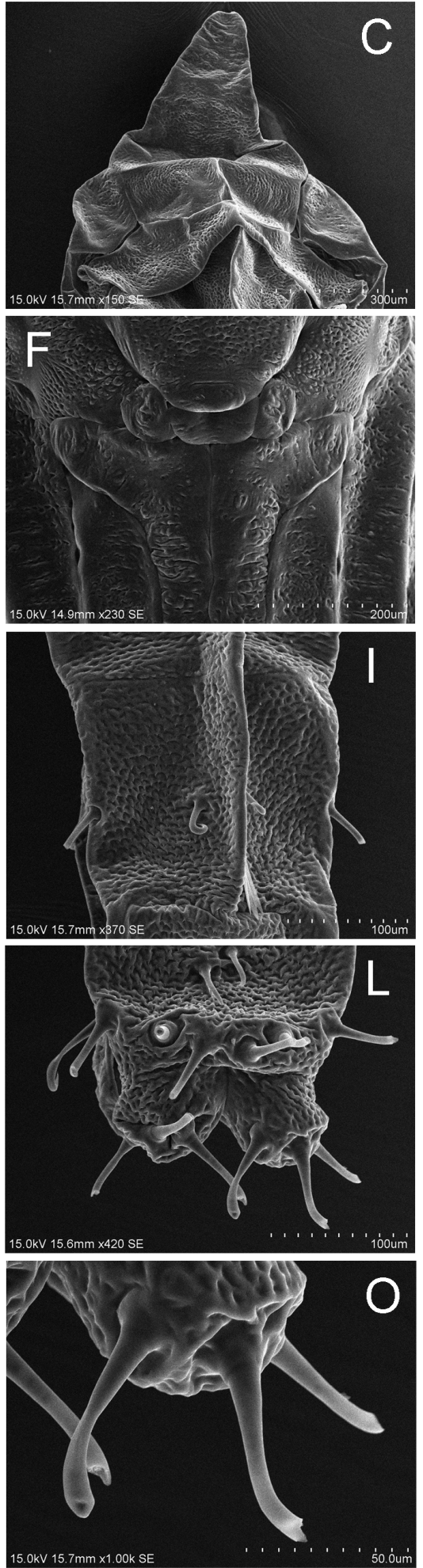

Fig. 17. SEMs of pupa of Bedellia somnulentella Zeller, 1847 (OPU-IN-LE2018IV0038-0039). A. Head, ventral view. B. Lateral view. C. Dorsal view. D. Frontal process, ventral view. E. Same, lateral view. F. Face, ventral view. G. Seta and spiracle of abdomen, lateral view. H. Spiracle. I. A7, dorsal view. J. A7-A10, dorsal view. K. Same, lateral view. L. Dorsal view. M. Setae of A10, ventral view. N. Same, lateral view. O. Dorsal view. 
KOBAYASHI S. et al., Designation of a new family group name, Tonzidae fam. nov.

looser webs than other yponomeutoid leaf-webbers. We observed that the larvae move on silk threads using the claws of the thoracic legs and the prolegs, but cannot move on flat surfaces without silk.

\section{Molecular analysis}

The COI DNA barcoding region (COI-5P) was sequenced from a Japanese specimen of Tonza. We performed sequence comparison to check species variation for T. citrorrhoa, using the BOLD Identification System (IDS) from the BOLD website (http://www.barcodinglife.org/) [accessed 1 Jul. 2016]. The DNA barcode sequence of T. citrorrhoa (Fig. 2, sample ID: SK-97) was clearly distinguished from that of T. purella registered in BOLD with more than 3\% pairwise divergence (Fig. 2) and to a sample from Madagascar belonging to BIN BOLD:ACU1104 by $2.91 \%$ pairwise divergence. The nearest neighbour of $T$. citrorrhoa in the BOLD database which is $0.35 \%$ pairwise divergent is a Taiwanese conspecific specimen (Fig. 2), which belongs to the same BIN (BOLD:ACX8102).

Figure 13 shows a maximum likelihood tree of the DNA barcoding region from 23 species of Yponomeutoidea and Gracillarioidea Stainton, 1854, including our sequence, SK-97. This tree based on a single locus could not resolve all the higher-level relationships within the groups, except for Attevidae Mosher, 1916 (85\% bootstrapping support). The traditional sense of Plutellidae, which would comprise Plutella Schrank, 1802, Orthenches Meyrick, 1885, and Tonza, among other taxa not represented here, did not form a monophyletic group. Two species, T. citrorrhoa and Glyphipterix equitella Scopoli, 1763, were grouped together with $87 \%$ bootstrapping support.

\section{Discussion}

\section{Morphology}

Historically, the genus Tonza had been associated with Yponomeutidae (Philpott 1927, who also noted the four-segmented maxillary palp as an exception; Common 1966) or Plutellidae (Common 1990; Heppner 1992), until Kobayashi et al. (2015) discussed its similarities with and possible association to Attevidae based essentially on male genitalic features: the presence of uncal processes and socii and the shape of the pleural lobes in the abdomen. Kobayashi et al. (2015) also mentioned that the genitalia of Stachyotis Meyrick, 1905 are similar to those of Tonza. Stachyotis is another genus whose plutellid association was defined merely by superficial similarity (Sohn 2014). However, Table 2 shows many characteristics in the genitalia are homoplastic among yponomeutoids and thus their phylogenetic value needs to be carefully evaluated. Immature stages as well as molecular data may help in defining the systematic position of Tonza. Such information has not been available or analysed until the present study.

We examined the immature stages and some additional adult characters of Tonza and compared it with other yponomeutoids (Table 2, Fig. 14). Our examination supports the designation of a new family group name, Tonzidae fam. nov., for Tonza. Tonzidae fam. nov. is clearly distinguished from other families of Yponomeutoidea by larval prolegs absent on A5 and A6. Larvae of other families possess prolegs on A3-A6, while several families have reduced prolegs. For example, the prolegs on A3 and A6 of Bedelliidae are shorter than those on A4 and A5 (Fig. 16A). The larval proleg modifications are curious and might relate to locomotion on silk threads as mentioned above. Mature larvae of Tonza have a very long seta MD1 on the head. This character also occurs in Yponomeutidae (Yponomeutinae and Saridoscelinae) and Scythropiidae Friese, 1966. Yponomeutine larvae possess a cervical gland (adenosma) on $\mathrm{T} 1$ that has been presumed to be an exocrine organ producing a trail-pheromone, used for orientation and homing (Povel \& Beckers 1982). This character is not found in other yponomeutoid groups, including Tonza. However, the larvae of Tonza and Bedellia (Bedelliidae) possess a gland-like structure ventrally on T1 (Figs 4F, 16B, D). Furthermore, an endocrine gland-like structure is found in the larvae of Bedellia inside the body (Fig. 16), but not in the larvae of Tonza. 
The pupa of Tonza is also similar to that of Bedelliidae (Table 2, Fig. 15K) in having a triangular single frontal process on the head (Figs 10A-D, 16F, 17A-E). The larva of Lyonetia Hübner, 1825 (Lyonetiidae Stainton, 1854) forms a hammock-shaped cocoon similar to Tonza and Bedelliidae, but the pupa differs from the latter two in possessing two frontal processes on the head and straight setae on the cremaster (Ahn et al. 2004; Kobayashi 2015).

\section{Molecular phylogeny}

Unexpectedly, our ML tree showed a close relationship between Tonza and Glyphipterix (Glyphipterigidae: Glyphipteriginae) (Fig. 13). The multigene analyses by Sohn et al. (2013) supported the family Glyphipterigidae comprising three subfamilies, Glyphipteriginae, Acrolepiinae Heinemann , 1870, and Orthoteliinae Herrich-Schaffer, 1857. Our COI phylogeny failed to recover such relationships. Tonza may be related with Glyphipteriginae and in that case, suggest that it is a member of Glyphipterigidae. We, however, could not find any morphological characteristic associating Tonza with Glyphipterigidae. Our phylogeny based on a single gene was not sufficient to resolve the association of Tonza with Glyphipterigidae. This issue needs to be explored with a much larger molecular dataset that is currently under construction.

The larval and pupal morphological features of Tonza exclude its associations with all existing families in Yponomeutoidea. Therefore, we propose a new family group name, Tonzidae fam. nov., to accommodate these unique characteristics of Tonza. This hypothesis is now available for further phylogenetic testing using new data and any other existing members of this new taxon need to be searched for and examined. The family-level rank itself needs to be confirmed with a much larger molecular dataset that is currently under construction.

\section{Host association}

The hostplantrelationship of Tonza uncovered from this study is novel for Yponomeutoidea. Putranjivaceae seems to be the only non-Brassicaceae plant lineage containing mustard oil glucosides, a convergence with Brassicaceae Burnett (Hall et al. 2002). It would therefore be interesting to check other members of the Indo-Australian genus Putranjiva Wall., as well as the more widely distributed Drypetes Vahl for larvae of Tonza, and also other members of this family (e.g., Lingelsheimia Pax). The new relationship gives a strong clue to discover early stages elsewhere in the World. Since Tonza is now removed from Plutellidae (a group like Pierinae Swainson, 1820 that has radiated on Brassicaceae), the ability to feed on plants with mustard oils (iso-thiocyanates: Puntambekar 1950) could be a symplesiomorphy or a convergence.

\section{Acknowledgments}

We express our special thanks to Mr A. Miyano (Gifu) for providing material and kind assistance, and Dr F. Komai (Art and Primary Education Department, Osaka University of Arts) and Mr. T. Sano (Tokyo) for providing larvae. We also specially thank Ass. Prof. N. Hirai and Dr S. Ueda (Entomological Laboratory, OPU) for their kind guidance and suggestions. The first author (Kobayashi) wishes to express his cordial thanks to the members of the Entomological Laboratory (OPU) for their kind advice and help. The last author thanks Jacques Rochat and Maik Bippus regarding information on Réunion, Joël Minet for discussion and Paul Hebert for updated information on BOLD. The fourth author (JCS) especially thanks Dr. Ian Sims (Syngenta International Research Centre, Berkshire) for providing research samples. 
KOBAYASHI S. et al., Designation of a new family group name, Tonzidae fam. nov.

\section{References}

Ahn N.H., Hirowatari T. \& Kuroko H. 2004. Immature stages of Lyonetia euryella Kuroko (Lepidoptera, Lyonetiidae). Transactions of the Lepidopterological Society of Japan 55 (3): 196-202.

Brown J.M., Pellmyr O., Thompson J.N. \& Harrison R.G. 1994. Phylogeny of Greya (Lepidoptera: Prodoxidae) based on nucleotide sequence variation in mitochondrial cytochrome oxidase I and II: congruence with morphological data. Molecular Biology and Evolution 11: 128-141. https://doi.org/10.1093/oxfordjournals.molbev.a040087

Common I.F.B. 1966. Australian Moths. Jacaranda Press, Brisbane.

Common I.F.B. 1990. Moths of Australia. Melbourne University Press, Carlton.

Dugdale J.S., Kristensen N.P., Robinson G.S. \& Scoble M.J. 1998. The Yponomeutidae. In: Kristensen N.P. (ed.) Lepidoptera, Moths and Butterflies. Vol. 1. Evolution, Systematics, and Biogeography. Handbook of Zoology 4: 119-130. Walter de Gruyer, Berlin.

Folmer O., Black M., Hoeh W., Lutz R. \& Vrijenhoek R. 1994. DNA primers for amplification of mitochondrial cytochrome c oxidase subunit I from diverse metazoan invertebrates. Molecular Marine Biology and Biotechnology 3: 294-299.

Hall J.C., Sytsma K.J. \& Iltis H.H. 2002. Phylogeny of Capparaceae and Brassicaceae based on chloroplast sequence data. American Journal of Botany 89 (11): 1826-1842. https://doi.org/10.3732/ajb.89.11.1826

Heppner J.B. 1992. Plutellidae. In: Heppner J.B. \& Inoue H. (eds) Checklist. Lepidoptera of Taiwan 1 (2): 74. Association for Tropical Lepidoptera, USA.

Kearse M., Moir R., Wilson A., Stones-Havas S., Cheung M., Sturrock S., Buxton S., Cooper A., Markowitz S., Duran C., Thierer T., Ashton B., Mentjies P. \& Drummond A. 2012. Geneious Basic: an integrated and extendable desktop software platform for the organization and analysis of sequence data. Bioinformatics 28 (12): 1647-1649. https://doi.org/10.1093/bioinformatics/bts 199

Kobayashi S. 2015. Biological notes on Lyonetia (Lyonetiola) castaneella (Lepidoptera: Lyonetiidae), with a new hostplant from Japan. Lepidoptera Science 66 (3): 90-95.

Kobayashi S., Sohn J.-C., \& Yoshiyasu Y. 2015. Reevaluation of the systematic position of the genus Tonza Walker (Yponomeutoidea: family incertae sedis), based on Tonza citrorrhoa Meyrick, new to Japan. Lepidoptera Science 66 (2): 68-76.

Kyrki J. 1984. The Yponomeutoidea: a reassessment of the superfamily and its suprageneric groups (Lepidoptera). Entomologica Scandinavica 15: 71-84. https://doi.org/10.1163/187631284X00064

Kyrki J. 1990. Tentative reclassification of holarctic Yponomeutoidea (Lepidoptera). Nota Lepidopterologica 13: 23-42.

Meyrick E. 1905. Descriptions of Indian Micro-Lepidoptera. The Journal of the Bombay Natural History Society 16: 614.

Meyrick E. 1913. Exotic Microlepidoptera, 1. Exotic Microlepidoptera, 1, Thornhanger, Marlborough: 146. https://doi.org/10.5962/bhl.title.9241

Nasu Y., Yasuda K., Arita Y., Ahn N.H. \& Hirowatari T. 2011. Yponomeutoidea. In: Komai F., Yoshiyasu Y., Nasu Y. \& Saito T. (eds) A guide to the Lepidoptera of Japan: 162-184. Tokai University Press, Kanagawa. [In Japanese.]

Philpott A. 1927. The maxillae in the Lepidoptera. Transactions of the New Zealand Institute 57: 721746. 
Povel G.D.E. \& Beckers M.M.L. 1982. The prothoracic 'defensive' gland of Yponomeutalarvae (Lepidoptera, Yponomeutidae). Proceedings of the Koninklijke Nederlandse Akademie van Wetenschappen. Series C 85 (3): 393-398.

Puntambekar S.V. 1950. Mustard oils and mustard oil glucosides occurring in the seed kernels of Putranjiva roxburghii Wall. Proceedings of the Indian Academy of Sciences A 32: 114.

Seino A. 2016. Tonza citrorrhoa Meyrick (Yponomeutoidea incertae sedis) and Naccaba sumptualis Walker (Noctuidae) collected from Amami-oshima Island, Kagoshima Prefecture. Yugato 226: 112. [In Japanese.]

Sohn J.-C. 2014. A taxonomic review of Stachyotis (Lepidoptera: Yponomeutoidea: Plutellidae) with description of a new species from China. Florida Entomologist 97 (4): 1588-1593. https://doi.org/10.1653/024.097.0431

Sohn J.-C. \& Nishida K. 2011. A taxonomic review of Eucalantica Busk (Lepidoptera, Yponomeutidae) with descriptions of six new species. Zookeys 118: 75-96. https://doi.org/10.3897/zookeys.118.956

Sohn J.-C., Regier J.C., Mitter C., Davis D., Landry J.-F., Zwick A. \& Cummings M. 2013. A molecular phylogeny of Yponomeutoidea (Insecta, Lepidoptera, Ditrysia) and its implications for classification, biogeography and the evolution of host plant use. PLOS ONE 8 (1): e55066. https://doi.org/10.1371/journal.pone.0055066

Stehr F. (ed.) 1987. Immature Insects. Kendall/Hunt Publishing Company, Dubuque, Iowa.

Tamura K., Stecher G., Peterson D., Filipski A. \& Kumar S. 2013. Mega 6: molecular Evolutionary Genetics Analysis Version 6.0. Molecular Biology and Evolution 30 (12): 2725-2729. https://doi.org/10.1093/molbev/mst197

Umetsu K. 2016. A record of Tonza citrorrhoa Meyrick (Yponomeutoidea: family incertae sedis) from Iriomote-jima Island, the Ryukyus. Yugato 224: 38. [In Japanese.]

Walker F. 1864. List of the specimens of lepidopterous insects in the collection of the British Museum, Part XXIX, Tineites: 1011-1012.Trustees oftheBritishMuseum,London.https://doi.org/10.5962/bhl.title.58221

Manuscript received: 15 December 2017

Manuscript accepted: 22 February 2018

Published on: 12 June 2018

Topic editor: Gavin Broad

Desk editor: Alejandro Quintanar

Printed versions of all papers are also deposited in the libraries of the institutes that are members of the EJT consortium: Muséum national d'Histoire naturelle, Paris, France; Botanic Garden Meise, Belgium; Royal Museum for Central Africa, Tervuren, Belgium; Natural History Museum, London, United Kingdom; Royal Belgian Institute of Natural Sciences, Brussels, Belgium; Natural History Museum of Denmark, Copenhagen, Denmark; Naturalis Biodiversity Center, Leiden, the Netherlands; Museo Nacional de Ciencias Naturales-CSIC, Madrid, Spain; Real Jardín Botánico de Madrid CSIC, Madrid, Spain. 